\title{
Ichthyofauna of Wroclaw - the Odra River, its tributaries and the selected city reservoirs
}

\author{
Andrzej WitKowsKi*, Mariusz KLESZCZ**, Jan BlACHUTA***, Jan KOTUSZ*, \\ Jan KUSZNIERZ**** and Karol NAPORA** \\ *Museum of Natural History, Wrockaw University, Sienkiewicza 21, 50-335 Wroctaw, Poland; \\ e-mail:a.witkowski@biol.uni.wroc.pl; e-mail:kotusz@biol.uni.wroc.pl \\ **(1) Fish Breeding Center "Szczodre", Polish Angling Association, Wroclaw Branch, 55-095 Mirków, \\ Trzebnicka 90, Poland; e-mail: szczodre@pzw.wroclaw.pl; \\ (2) Kazimierza Wielkiego 64, 50-077 Wroctaw, Poland; e-mail: pankna@wp.pl \\ ***Department of Ecology, Institute of Meteorology and Water Management, \\ Parkowa 30,51-616Wroctaw, Poland; e-mail: jan.blachuta@imgw.wroc.pl \\ **** Department of Biology and Vertebrate Protection, Zoological Institute, Wroclaw University, \\ Sienkiewicza 21, 50-335 Wrocław, Poland; e-mail: kusznierz@biol.uni.wroc.pl
}

\begin{abstract}
The ichthyofauna of the Odra River, its major tributaries (Oława, Widawa, Bystrzyca, Ślęza) and selected reservoirs (sand and clay pits, city park ponds, recreational reservoirs, city moat) within the city of Wroctaw is described on the basis of data obtained in our own studies (electrofishing and net-catching), quality control catches of the Polish Angling Association, analysis of stocking registers, control and analysis of angling inquiries and interviewing anglers in 1980-2010. Forty six fish and lamprey species were recorded: 42 in the Odra River, and 41 in its tributaries. Twenty eight species were recorded from the city reservoirs; they represented euryoecious and stagnophilous ecological groups. The study area holds nine species which are legally protected in Poland (Lampetra planeri, Acipenser oxirynchus, Gobio albipinnatus, Rhodeus sericeus, Eupallasella percnurus, Cobitis taenia, Sabanejewia baltica (=aurata), Misgurmus fossilis, Barbatula barbatula) and five species regarded as endangered in the country (Barbus barbus, Vimba vimba, Chondrostoma nasus, Hucho hucho, Salmo salar). Eleven species occurring in the water courses and reservoirs of Wroclaw are protected within the EU Habitats Directive (92/43/EWG). Ten species introduced accidentally or on purpose occur in the city. Despite the high anthropopressure, including intensive angling, the Wroclaw waters still hold diverse, and the Odra River itself - even rich - fish communities.
\end{abstract}

Key words: Wrocław, Odra River, ichthyofauna, human impact, regulated/navigated river, urban resevoirs

\section{INTRODUCTION}

Wroclaw is located at the confluence of the rivers Olawa, Bystrzyca, Ślęża, Widawa and 12 other small streams with the Odra, the largest river of Silesia (Malachowicz 2000, Czerwiński 2002, Żerelik 2002). Since the beginnings of its history the city has been famous for its abundance of fish. This is testified to, among other things, by archaeological data and the mediaeval written record (Dembińska 1963, Kozikowska 1974, Witkowski \& Żerelik 2001). The fish abundance resulted from the unusual richness of all the river branches and numerous oxbows which constituted rich feeding grounds and spawning grounds of many species (Pax 1925). The Odra itself was a migration route for many fish species which travelled to their spawning grounds in the upper part of the river system (Wiśniewolski \& Engel 2006). The large-scale canalising of the river and partitioning the Odra and its tributaries with numerous dams, weirs and locks which started in the 19th c. (Bartosiewicz 1995), the many-century overexploitation and pollution with industrial and communal waste, resulted in an interruption of these migration routes (Blachuta \& Kusznierz 1995). As a result, some species (Petromyzon marinus, Lampetra fluviatilis, Acipenser oxirynchus, Alosa alosa, Osmerus eperlanus, Salmo 
salar, Salmo trutta m. trutta, Pelecus cultratus), disappeared from the region, and a few (Barbus barbus, Vimba vimba, Chondrostoma nasus, Silurus glanis, Aspius aspius) for a long time remained on the brink of extinction (Witkowski et al. 2000, Kotusz et al. 2001).

A gradual restitution of the most endangered or regionally extinct species started the end of the 20th c., after successful limiting or removal of most of these adverse factors, (Kleszcz et al. 2001, Witkowski et al. 2001, 2002, 2004a,c), although the ecological patency of the Odra and the mouth sections of its tributaries for migratory species in the environs of Wroclaw is still much limited (Blachuta \& Kusznierz 1995, Kotusz et al. 2006, Wiśniewolski \& Engel 2006, Blachuta et al. 2010b).

The objective of this paper is to present the current state of the ichthyofauna of the city of Wroclaw. Expanding and updating the knowledge of the fishes inhabiting waters of large city agglomerations is important from the point of view of natural history and because of the potential recreational significance of such waters (angling).

\section{STUDY AREA - WROCŁAW, ITS RIVERS AND RESERVOIRS}

The river system of Wroclaw is composed of five rivers (Odra, Olawa, Ślęza, Bystrzyca and Widawa) and several small, much modified streams, mostly temporary. According to the abiotic typology of the Polish rivers (Blachuta et al. 2010a), the Odra is a large lowland river (type 21), the Olawa, Ślęza and Widawa are sandy-clayey lowland rivers (type 19), whereas the Bystrzyca is a gravelly lowland river (type 20). The water quality in all these rivers does not meet the requirements of good quality (Raport 2010). In the Odra, Olawa, Ślęza and Bystrzyca the water contains too much harmful substances, and all the rivers are below the limit of good ecological potential. The water in none of the rivers meets requirements for cyprinid fishes; the too high nitrite content is the disqualifying parameter.

The Odra is the main river of Wroclaw. Its catchment area till the city boundaries is 20 $399 \mathrm{~km}^{2}$, and below the mouth of the last tributary within the city boundaries - Widawa - it increases to $24169 \mathrm{~km}^{2}$ (Czarnecka 2005). The mean flow in the Odra below Wroclaw is $171 \mathrm{~m}^{3} / \mathrm{s}$ (Szczepański 1996).

The Odra is morphologically much modified. Two canals separate from it within Wroclaw: Navigation Canal and Flood Canal, as well as Stara Odra [=Old Odra]. The two canals connect with the Stara Odra. Before the connection with the Navigation and Flood canals, the City Canal separates from the Stara Odra and re-connects with it just before the junction of the Stara Odra with the Odra. The main bed of the Odra in the city centre divides in two branches - Southern Odra, with most of the flow, and Northern Odra. The two branches merge just before the junction of the Odra and Stara Odra. The morphological continuity of the Odra, Stara Odra and the canals is interrupted by weirs (going upstream: one weir with hydro power station on the Southern and Northern Odra, three weirs on the Stara Odra, one on the Flood Canal, one on the Odra below the separation of the canals). Two weirs with chamber fish passes are located below Wrocław (Wały Śląskie and Rędzin). From the weir in Waly Sląskie till its estuary to the Gulf of Szczecin the Odra preserves its morphological continuity. About a dozen weirs are situated on the Odra also above Wroclaw.

The bed of the Odra, Stara Odra and the canals is regulated, to a large extent straightened, and the banks are reinforced with loose stones; the same is true of the bottom of the canals and Stara Odra. In the Stara Odra and Navigation Canal the bottom reinforcement is covered by gravel and sands, in the Flood Canal the bottom is stony. The whole city section of the Odra is devoid of natural oxbows connected to the river bed. To some extent their role is played by artificial coves - two wintering harbours for barges, avantports near locks and coves at yachting harbours. On short sections, especially in the 
meanders between the heads, compact reed beds have formed. Patches of Potamogeton sp. and Myriophyllum sp. occur sporadically near the banks.

The Olawa (left bank tributary to the main Odra bed) joins the Odra on the $509.9 \mathrm{~km}$ of its course, in the centre of Wroclaw. It is much modified morphologically (its continuity is preserved only till the 4 th $\mathrm{km}$ of its course) and hydrologically; most of the flow is abstracted by the Wroclaw waterworks (mean flow $3.4 \mathrm{~m}^{3} / \mathrm{s}$, waterworks intake ca. $2 \mathrm{~m}^{3} / \mathrm{s}$ ). The bottom is sandy, with well developed macrophytes and dominance of Nuphar luteum.

The Ślęza (left bank tributary) joins the Odra on the $498.9 \mathrm{~km}$, below the junction of all the city branches of the river and below the Rędzin weir. The mean flow in the Ślęza is $2.9 \mathrm{~m}^{3} / \mathrm{s}$. It is a canalised river with sandy bottom and banks reinforced with loose stones. Its morphological continuity is preserved only till the $3 \mathrm{rd} \mathrm{km}$ of the course, that is till the weir without fish passes and with a hydro power station.

The Bystrzyca (left bank tributary) joins the Odra on the $494.1 \mathrm{~km}$, its mean flow is 9.4 $\mathrm{m}^{3} / \mathrm{s}$. The morphological continuity is preserved till the $4.2 \mathrm{~km}$ of the course, till the weir and power station in Marszowice. Below the power station the bottom is stony and gravelly, at the mouth to the Odra - sandy. No macrophytes are present.

The Widawa (right bank tributary) joins the Odra on the $493.7 \mathrm{~km}$. The mean flow in the Widawa is $7.4 \mathrm{~m}^{3} / \mathrm{s}$. Its morphological continuity is preserved till the 25 th $\mathrm{km}$ of the course (the weir on the $6.6 \mathrm{~km}$ is open for most of the year, the threshold on the $12.4 \mathrm{~km}$ is low and prevents fish migration only during very low water level). The bottom is sandy, with much gravel; the macrophytes are well developed (Potamogeton sp., less often Nuphar luteum) on long sections covering over $80 \%$ of the bottom.

The stagnant waters of the city are much transformed former oxbows of the Odra (pond in Szczytnicki park, recreational pond Morskie Oko, pond in the Botanical Garden, pond Kozanów, City Moat) and Olawa (pond in Park Poludniowy), deepened depressions (pond at Anielewicza street, pond in S. Tolpa Park) and clay pits (AMW recreational pond at Skarbowców street, clay pits in Pilczyce, Kosmonautów Str., in Żerniki, Maślice and Pracze Odrzańskie).

Most of the former oxbows have no surface connection with the rivers (except for the City Moat). They are shallow, the mean depth ranges from $0.5 \mathrm{~m}$ (pond in Szczytnicki park) to 1.5 m (City Moat, recreational pond Morskie Oko). Except the City Moat and the recreational pond Morskie Oko they are much eutrophicated, with long-lasting summer algal blooms and winter oxygen deficits.

The deepened hollows - ponds dug in former marshy areas (pond in S. Tolpa park, pond at Anielewicza street) have the mean depth of ca. $1 \mathrm{~m}$, are much eutrophicated, with green-blue algal blooms persisting from May till October and summer oxygen deficits. They have efficient springs in their bottoms, so that the ice cover is short lasting and oxygen is not exausted in winter.

The clay pits are deep (mean depth exceeding $2 \mathrm{~m}$ ), with well developed macrophytes (except the recreational pond at Skarbowców street). Algal blooms occur only in August and September.

\section{MATERIAL AND METHODS}

Results of our own studies conducted within the long-term research project „The ichtiofauna of Silesia", which included, among others, the Odra River and its tributaries joining the river within the boundaries of Wroclaw (Witkowski \& Blachuta 1991a,b, Witkowski et al. 1991a,b, 1992a,b, 2000, Kotusz et al. 1996, 2001, Witkowski \& Paszkowski 2002) were used to compile a species list and assess the fish resources in the Wroclaw waters. 


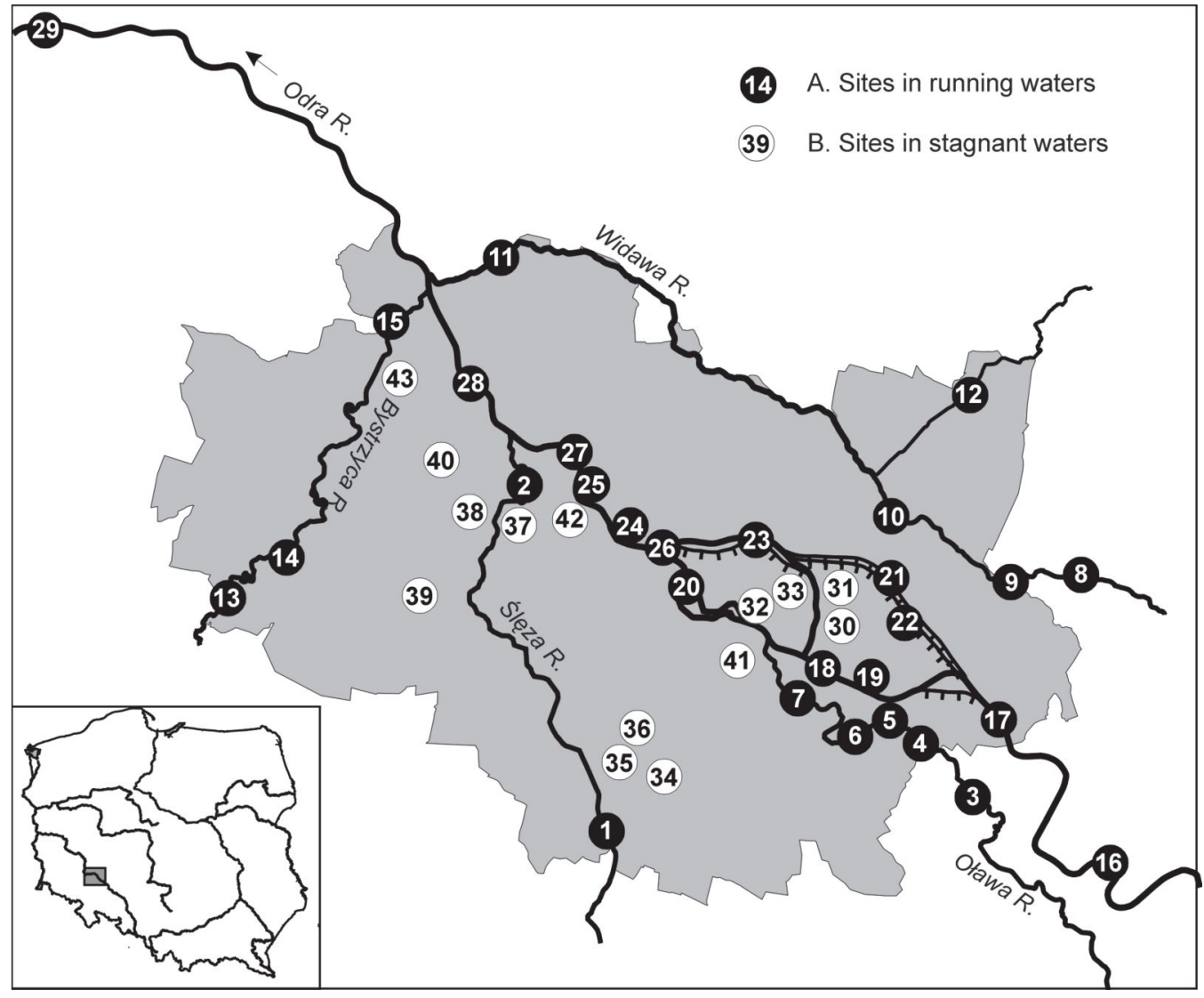

Fig. 1. Sites of fish sampling located in the waters of the Wroctaw - the Odra River, its tributaries (A) and the city reservoirs (B):

A. Rivers: 1. Ślęza R., Wrocław-Klecina, 2. Ślęza R., Wrocław-Pilczyce, 3. Oława R., Wrocław-Radwanice, 4. Oława R, Wrocław-Mokry Dwór, 5. Oława R., Wrocław - cove „Nowy Dom”, 6. Oława R., Wrocław-Park Wschodni, 7. Oława R., Wrocław-Niskie Łąki („Kapielisko Oławka”), 8. Widawa R., Wrocław-Kiełczów, 9. Widawa R., WrocławWilczyce, 10. Widawa R., Wrocław-Psie Pole, 11. Widawa R., Wrocław-Świniary, 12. Dobra R., Proszowice Wrocław-Zakrzów, 13. Bystrzyca R., Wrocław-Jarnoltów, 14. Bystrzyca R., Wrocław-Ratyń, 15. Bystrzyca R., Wrocław-Pracze Odrzańskie, 16. Odra R., Ratowice - Łany, 17. Odra R., Lany - Opatowicka Island, 18. Odra R., Opatowicka Island - Politechnika Wrocławska, 19. Odra R, Wrocław-Biskupin (cove „Stanica Wodna ZHP”), 20. Odra R., city sector (Politechnika Wrocławska-Popowice), 21 Odra R., navigation canal (Bartoszowice weir Warszawski bridge), 22. Odra R., storm canal (Bartoszowice weir - Warszawski bridge), 23. Odra R., WrocławKarłowice - Różanka, 24. Odra R., Wrocław-Popowice (branch at Milennium bridge), 25. Odra R., WrocławPopowice/ Osobowice (cove, barge winter habour), 26. Odra R., Wrocław-Różanka - Popowice/ Osobowice, 27. Odra R., Wrocław-Popowice - Rędzin, 28. Odra R., Wrocław-Rędzin - mouth of Bystrzyca and Widawa, 29. Odra R., Brzeg Dolny („Waly Śląskie”);

B. Wroclaw - city reservoirs (park ponds, clay and gravel pits, city moat and others): 30. pond, Szczytnicki Park, 31. recreational pond („Morskie Oko”), 32. pond in the Botanical Garden University of Wrocław, 33. pond, Tołpa St. Park (Nowowiejska Street), 34. pond, Southern Park, 35. recreational pond „AMW” (Skarbowców Street), 36. pond (Anielewicza Street), 37. clay pit, Pilczyce (Papiernicza Street), 38. recreational pond „Glinianki” (Kosmonautów Street), 39. clay pits, Żerniki ( M. Przybyły Street), 40. clay pits, Maślice, 41. city moat, 42. pond, Kozanów, 43. clay pit, Pracze Odrzańskie (Brodzka Street).

For comparative purposes we used the data from sections of the Odra located from a few to about a dozen kilometres above and below the boundaries of the city. During the studies the fishes were caught with electrofishing equipment, from a boat or wading upstream, according 
to the commonoly accepted methods of river catches (Penczak 1967, Backiel \& Penczak 1989). The results of studies on fish migrations in the Odra served to supplement the species list and assess the relative abundance of fishes; during these studies, after stopping the water flow in the chambers of the fish pass at the hydro power plant ,Waly Ślqskie”, extensive material was obtained (over 31 thousand individuals) of 22 fish species (Witkowski et al. 2004c, Kotusz et al. 2006).

Besides, we used the results of the quality assessment catches (electrofishing and netcatching) by the Polish Angling Association [PZW], as well as stocking and catch reports by the Wroclaw Branch of PZW, and catch registers (3860 of 2005-2008) submitted by anglers, data obtained during angling contests where some of the authors were members of the jury, and data from anglers collected during several hundred field inquiries.

The analysed data come from 1980-2010. Data from a total of 43 localities were included in this study (Fig.1). They include 14 sections/stations of the Odra, its canals, side branches and coves (natural and artificial) over the river length of $39.3 \mathrm{~km}$ - from Ratowice $(533 \mathrm{~km}$ of the river, $121 \mathrm{~m}$ a.s.1.) to the mouths of Widawa and Bystrzyca $(493.7 \mathrm{~km}$ of the river, $107.5 \mathrm{~m}$ a.s.l.). Besides, data from 15 localities in the mouth sections of four tributaries: Olawa, Ślęza, Widawa and Bystrzyca, were used, as well as those from 14 urban reservoirs of different origin and character (ponds, oxbows, park ponds, municipal moat etc.); these data were collected with the above-described methods.

Classification of lampreys and fishes follows Nelson (2006). The species composition of the ichthyofauna and the estimated dominance of individual species are presented in tables. Constancy of occurrence (C) $\left[C(\%)=100 N_{s} N_{t}\right.$, where $N_{s}$ - number of localities/reservoirs with the species; $N_{t}$ - total number of localities/reservoirs] is given. Classification of preferences with respect to water flow follows Schiemer \& Waidbacher (1991), assignment to reproductive guilds - Balon (1975). Assignment of species to threat categories was adopted after Głowaciński (2001) and Witkowski et al. (2009).

\section{RESULTS}

\section{Species composition and ecological characteristics of the ichthyofauna}

The total number of lamprey and fish species inhabiting the waters of Wroclaw at present or during the studies is 46 . Forty two species were recorded from the Odra (in 14 localities), from 11 to 39 per site (mean 31), 41 species - from the tributaries, from 9 to 34 per site (mean 21). The 14 city reservoirs harboured a total of 28 species, $1-13$ per reservoir (mean 12) (Table 1). Besides, three interspecific hybrids of cyprinids were recorded from the studied area.

The species with the highest constancy $(\mathrm{C}>70 \%)$ values were Rutilus rutlilus, Perca fluviatilis, Scardinus erythrophthalmus, Esox lucius, Tinca tinca, Abramis bjoerkna, Gasterosteus aculeatus, Carassius gibelio, Leuciscus idus, Cyprinus carpio, Carassius carassius, Alburnus alburnus (Table 2).

In the running waters the group of dominants and subdominants was composed of rheophilous species and species of higher oxygen requirements: Gobio gobio, Abrama brama, Leuciscus leuciscus, L. idus, L. cephalus, Alburnus alburnus, ubiquitous species such as Perca fluviatilis, Gymnocephalus cernuus and economically valuable species, such as Cyprinus carpio, Aspius aspius, Silurus glanis, Esox lucius, Lota lota and Sander lucioperca, constituting popular angling objects. In the stagnant waters, besides Esox lucius and Tinca tinca, limno- and stagnophilous species of little value were recorded: Carassius gibelio, Rutilus rutilus, Scardinius erythrophthalmus, Leucaspius delineatus, Ameiurus nebulosus, Gasterosteus aculeatus and Perca fluviatilis. 
Table 1. Species composition and estimated abundance of fishes and lampreys from rivers and reservoirs of the Wroclaw; +++ very abundant species; ++ abundant species; + not abundant; $(\mathrm{x})$ very rarely recorded or occurrence uncertain

\begin{tabular}{|c|c|c|c|c|}
\hline No. & Species & Odra River & $\begin{array}{c}\text { Affluents of } \\
\text { the Odra } \\
\text { River }\end{array}$ & $\begin{array}{l}\text { Park ponds, } \\
\text { clay and sand- } \\
\text { pits and others }\end{array}$ \\
\hline 1. & Book lamprey - Lampetra planeri & - & + & - \\
\hline 2. & Baltic sturgeon - Acipenser oxirynchus & (x) & (x) & - \\
\hline 3. & Eel - Anguilla anguilla & + & + & $(\mathrm{x})$ \\
\hline 4. & Barbel - Barbus barbus & + & + & - \\
\hline 5. & Carp - Cyprinus carpio & + & + & + \\
\hline 6. & Crucian carp - Carassius carassius & + & + & ++ \\
\hline 7. & Giebel - Carassius gibelio & +++ & ++ & + \\
\hline 8. & Grass carp - Ctenopharyngodon idella & + & + & + \\
\hline 9. & Gudgeon - Gobio gobio & ++ & +++ & $(\mathrm{x})$ \\
\hline 10. & White-fin gudgeon - Gobio albipinnatus & ++ & - & - \\
\hline 11. & Tench - Tinca tinca & + & ++ & ++ \\
\hline 12. & Bitterling - Rhodeus sericeus & ++ & ++ & + \\
\hline 13. & Common bream - Abramis brama & +++ & ++ & + \\
\hline 14. & Silver bream - Abramis bjoerkna & +++ & ++ & ++ \\
\hline 15. & Blue bream - Abramis ballerus & ++ & + & - \\
\hline 16. & Vimba - Vimba vimba & + & + & - \\
\hline 17. & Roach - Rutilus rutilus & +++ & +++ & ++ \\
\hline 18. & Rudd - Scardinius erythrophthalmus & + & + & ++ \\
\hline 19. & Nase - Chondrostoma nasus & + & + & - \\
\hline 20. & Silver carp - Hypophthalmichthys molitrix & + & - & $(\mathrm{x})$ \\
\hline 21. & Big-head carp - Aristichthys nobilis & + & - & - \\
\hline 22. & Asp - Aspius aspius & +++ & + & - \\
\hline 23. & Sunbleak - Leucaspius delineatus & + & ++ & ++ \\
\hline 24. & Swamp minnow - Eupallasella percmurus & - & - & (x) \\
\hline 25. & Dace - Leuciscus lenciscus & ++ & ++ & - \\
\hline 26. & Ide-Leusiscus idus & +++ & ++ & ++ \\
\hline 27. & Chub-Lenciscus cephalus & +++ & ++ & - \\
\hline 28. & Bleak - Alburnus alburnus & +++ & ++ & ++ \\
\hline 29. & Topmouth gudgeon - Pseudorasbora parva & - & + & + \\
\hline \multirow[t]{2}{*}{30.} & Spined loach - Cobitis taenia [Cobitis complex: & & & \\
\hline & C. taenia $\times$ C. elongatoides $]$ & ++ & ++ & - \\
\hline 31. & Golden loach - Sabanejewia baltica & - & + & - \\
\hline 32. & Mudd loach-Misgurnus fossilis & + & + & + \\
\hline 33. & Stone loach - Barbatula barbatula & ++ & + & - \\
\hline 34. & Pirapitinga-Piaractus brachypomus & - & - & (x) \\
\hline 35. & Brown bullhead - Ameiurus nebulosus & ++ & ++ & + \\
\hline 36. & Wels - Silurus glanis & ++ & + & $(\mathrm{x})$ \\
\hline 37. & Pike-Esox lucius & ++ & ++ & + \\
\hline 38. & Huchen - Hucho hucho & $(\mathrm{x})$ & - & - \\
\hline 39. & Salmon - Salmo salar & + & $(\mathrm{x})$ & - \\
\hline 40. & Sea trout - Salmo trutta m. trutta & + & $(\mathrm{x})$ & - \\
\hline 41. & Brown trout - Salmo trutta m. fario & $(\mathrm{x})$ & + & - \\
\hline 42. & Rainbow trout - Oncorhynchus mykiss & $(\mathrm{x})$ & + & $(\mathrm{x})$ \\
\hline 43. & Burbot - Lota lota & + & ++ & - \\
\hline 44. & Stickleback - Gasterosteus aculeatus & ++ & ++ & ++ \\
\hline 45. & Perch-Percafluviatilis & +++ & +++ & + \\
\hline 46. & Pike-perch - Sander lucioperca & ++ & + & (x) \\
\hline \multirow[t]{2}{*}{47.} & Ruff - Gymnocephalus cermuus & +++ & ++ & + \\
\hline & Number of species & 42 & 41 & 28 \\
\hline
\end{tabular}


Table 2. Constancy of occurrence (C) of fish and lamprey species within the city of Wroclaw: Odra, its tributaries and city reservoirs; $\mathbf{n}$ - number of localities

\begin{tabular}{|c|c|c|c|c|c|}
\hline No. & Species & $\begin{array}{c}\text { Wroclaw City: } \\
\text { all aquatic } \\
\text { ecosystems } \\
(n=43)\end{array}$ & $\begin{array}{c}\text { Odra River } \\
(n=14)\end{array}$ & $\begin{array}{c}\text { Affluents of the } \\
\text { Odra River } \\
(n=15)\end{array}$ & $\begin{array}{c}\text { Park ponds, clay- } \\
\text { sand pits \& } \\
\text { others } \\
(\mathrm{n}=14)\end{array}$ \\
\hline 1. & Lampetra planeri & 2.3 & - & 6.7 & - \\
\hline 2. & Acipenser oxirynchus & 7.0 & 13.3 & 7.1 & - \\
\hline 3. & Anguilla anguilla & 34.9 & 71.4 & 33.3 & 14.3 \\
\hline 4. & Barbus barbus & 27.9 & 50.0 & 33.3 & - \\
\hline 5. & Cyprinus carpio & 72.1 & 92.8 & 53.3 & 57.1 \\
\hline 6. & Carassius carassius & 69.8 & 100.0 & 33.3 & 71.4 \\
\hline 7. & Carassius gibelio & 74.4 & 92.8 & 53.3 & 78.6 \\
\hline 8. & Ctenopharyngodon idella & 53.5 & 85.7 & 33.3 & 42.8 \\
\hline 9. & Gobio gobio & 60.5 & 86.7 & 80.0 & 7.1 \\
\hline 10. & Gobio albipinnatus & 23.2 & 71.4 & - & - \\
\hline 11. & Tinta tinca & 83.2 & 92.8 & 66.7 & 92.8 \\
\hline 12. & Rhodeus sericeus & 55.8 & 71.4 & 66.7 & 28.6 \\
\hline 13. & Abramis brama & 69.7 & 92.8 & 73.3 & 42.8 \\
\hline 14. & Abramis bjoerkna & 74.4 & 92.8 & 73.3 & 57.1 \\
\hline 15. & Abramis ballerus & 51.2 & 78.6 & 73.3 & - \\
\hline 16. & Vimba vimba & 25.6 & 50.0 & 26.7 & - \\
\hline 17. & Rutilus rutilus & 90.7 & 100.0 & 100.0 & 71.4 \\
\hline 18. & Scardinitus erythrophthalmus & 88.4 & 85.7 & 86.6 & 92.8 \\
\hline 19. & Chondrostoma nasus & 34.9 & 71.4 & 33.3 & - \\
\hline 20. & Hypophthalmichthys molitrix & 30.2 & 85.7 & - & 7.1 \\
\hline 21. & Aristichthys nobilis & 16.3 & 50.0 & - & - \\
\hline 22. & Aspius aspius & 51.2 & 92.8 & 60.0 & - \\
\hline 23. & Leucaspius delineatus & 62.8 & 71.4 & 46.7 & 71.4 \\
\hline 24. & Eupallasella percnurus & 4.6 & - & - & 14.2 \\
\hline 25. & Lenciscus leuciscus & 46.5 & 78.6 & 60.0 & - \\
\hline 26. & Leusiscus idus & 72.1 & 100.0 & 73.3 & 42.8 \\
\hline 27. & Lenciscus cephalus & 67.4 & 85.7 & 86.7 & - \\
\hline 28. & Alburnus alburnus & 65.1 & 100.0 & 86.7 & 7.1 \\
\hline 29. & Pseudorasbora parva & 16.3 & - & 20.0 & 28.6 \\
\hline 30. & $\begin{array}{l}\text { Cobitis taenia [Cobitis complex: } \\
\text { C. taenia } \mathrm{x} \text { C. elongatoides] }\end{array}$ & 16.3 & 28.6 & 20.0 & - \\
\hline 31. & Sabanejewia baltica & 4.6 & - & 13.3 & - \\
\hline 32. & Misgurnus fossilis & 39.5 & 64.3 & 40.0 & 14.2 \\
\hline 33. & Barbatula barbatula & 37.2 & 57.1 & 53.3 & - \\
\hline 34. & Piaractus brachypomus & 4.6 & - & - & 14.2 \\
\hline 35. & Ameiurus nebulosus & 67.4 & 92.8 & 46.7 & 64.3 \\
\hline 36. & Silurus glanis & 51.2 & 85.7 & 85.7 & 28.6 \\
\hline 37. & Esox lucius & 86.4 & 100.0 & 85.7 & 64.3 \\
\hline 38. & Hucho hucho & 2.3 & 7.1 & - & - \\
\hline 39. & Salmo salar & 20.9 & 35.7 & 26.7 & - \\
\hline 40. & Salmo trutta m. trutta & 30.8 & 57.1 & 33.3 & - \\
\hline 41. & Salmo trutta m. fario & 13.9 & 7.1 & 33.3 & - \\
\hline 42. & Oncorhynchus mykiss & 18.6 & 14.2 & 33.3 & 7.1 \\
\hline 43. & Lota lota & 51.2 & 85.7 & 66.7 & - \\
\hline 44. & Gasterosteus aculeatus & 74.4 & 92.8 & 73.3 & 57.1 \\
\hline 45. & Perca fluviatilis & 88.4 & 100.0 & 93.3 & 71.4 \\
\hline 46. & Sander lucioperca & 62.8 & 85.7 & 86.6 & 7.1 \\
\hline 47. & Gymnocephalus cernuus & 62.8 & 92.8 & 60.0 & 42.8 \\
\hline
\end{tabular}


The Odra River is characterised by the greatest diversity in terms of the represented reproductive guilds: phytophiles were represented by 16 species, litophiles by 8 , phytolithophiles by 7 , psammophiles by 3 , partial pelagophiles by 3 , lithopelagiophiles, ostracophiles and special by 1 species each. Only four guilds were represented in the reservoirs, with the dominance of phytophiles (16), phytolithophiles (5), litophiles and ostracophiles, represented by 1 species each.

\section{Protected and endangered species}

Nine of the species occurring in the waters of Wroclaw are completely legally protected in Poland (Lampetra planeri, Acipenser oxirynchus, Gobio albipinnatus, Rhodeus sericeus, Eupallasella percnurus, Cobitis taenia, Sabanejewia baltica (=aurata), Misgurnus fossilis, Barbatula barabtula) (Dz. U. 2004). Besides, two species (Hucho hucho, Salmo salar) are included in the Red Data Book of the Animals of Poland (Glowaciński 2001). Ten lamprey and fish species of the most endangered categories (EX-VU) occur in the waters of Wroclaw; 6 species are nearly threatened (NT), and the occurrence of further 8 species (various threat categories, from EW to LC) depends on regular stocking (CD) (Witkowski et al. 2009). Eleven species are included in Annexes II and V of the EU Habitats Directive and protected within the European network Natura 2000 (Table 3).

Table 3. Placement of the most threats of the native fish and lamprey species of the Odra River and in Poland in threat criteria and categories IUCN (2001) and their legal status, according to Glowaciński (2002) and Witkowski et al. (2009); EXP - extinct in Poland, EXOW - extinct in the Odra River in Wroclaw region, EW - extinct in the wild, CR critically endangered, EN - endangered, VU - vulnerable, NT - near threatened, LC - least concern, CD -conservation dependent; $\mathbf{O G}$ - protected in Poland, $D S I I$ - included in Annex II of Habitats Directive, $D S V$ - included in Annex V of Habitats Directive.

\begin{tabular}{|c|c|c|c|c|}
\hline \multirow{2}{*}{ No. } & \multirow{2}{*}{ Species } & \multicolumn{2}{|c|}{ Category of threats } & \multirow{2}{*}{ Status } \\
\hline & & The Odra River mid course & Poland & \\
\hline 1. & Acipenser oxirynchus ${ }^{x}$ & EX OW & EX P & $\mathrm{OG}, D S I I, D S V$ \\
\hline 2. & Salmo salart & $\mathrm{EW} / \mathrm{CD}$ & $\mathrm{EW}$ & $D S I I . D S V$ \\
\hline 3 & Hucho hucho & Introduced & $\mathrm{EW}$ & $D S I I, D S V$ \\
\hline 4. & $\operatorname{Vimba}$ vimba ${ }^{x}$ & $\mathrm{CR} A \mathrm{l} / \mathrm{CD}$ & CR Al & - \\
\hline 5. & Eupallasella percnurus & Introduced & EN E & $\mathrm{OG}, D S I I$ \\
\hline 6. & Chondrostoma nasus* & $\mathrm{EN} \mathrm{AI-2/CD}$ & EN AI & - \\
\hline 7. & Lota lotat & VU A1 & VU Al & - \\
\hline 8. & Lampetra planeri & VU E & VUE & $\mathrm{OG}, D S I I$ \\
\hline 9. & Gobio albipinnatus & NT & VUE & $\mathrm{OG}, D S I I$ \\
\hline 10. & Sabanejewia baltical aurata & VU BI & VU BI-2 & $\mathrm{OG}, D S I I$ \\
\hline 11. & Rhodeus sericeus & VU B2 & VU AI & $\mathrm{OG}, D S I I$ \\
\hline 12. & Misgurnus fossilis & VU AI & VU AI & $\mathrm{OG}, D S I I$ \\
\hline 13. & Barbus barbus ${ }^{x}$ & $\mathrm{VU} B 1 / \mathrm{CD}$ & VU A2 & $D S V$ \\
\hline 14. & Aspius aspius & NT & $\mathrm{LC}$ & $D S I I, D S V$ \\
\hline 15 & $\begin{array}{l}\text { Cobitis taenia [Cobitis complex: } \\
\text { C. taenia } \mathrm{x} \text { C. elongatoides] }\end{array}$ & NT & NT & $\mathrm{OG}$ \\
\hline 16. & Carassius carassius & NT & NT & - \\
\hline 17. & Leuciscus leuciscus & NT & NT & - \\
\hline 18. & Silurus glanis ${ }^{x}$ & $\mathrm{NT} / \mathrm{CD}$ & $\mathrm{NT} / \mathrm{CD}$ & - \\
\hline 19. & Anguilla anguilla & $\mathrm{LC} / \mathrm{CD}$ & $\mathrm{LC} / \mathrm{CD}$ & - \\
\hline 20. & Salmo trutta m. trutta & $\mathrm{LC} / \mathrm{CD}$ & $\mathrm{LC} / \mathrm{CD}$ & - \\
\hline 21. & Salmo trutta $\mathrm{m}$ fario & $\mathrm{LC} / \mathrm{CD}$ & $\mathrm{LC} / \mathrm{CD}$ & - \\
\hline 22. & Barbatula barbatula & $\mathrm{LC}$ & $\mathrm{LC}$ & OG \\
\hline
\end{tabular}

\footnotetext{
$/ *$ - beginning of restitution
} 
Eight species of lamprey and fish disappeared from the Wroclaw section of the Odra (EXOW) at the end of the $19^{\text {th }}$ and the beginning of the $20^{\text {th }} \mathrm{c} .:$ Petromyzon marimus, Lampetra fluviatilis, Alosa alosa, Osmerus eperlanus, Pelecus cultratus (Witkowski et al. 2000), Acipenser oxirynchus, Salmo salar, S. trutta m. trutta; for a few years the last three have been gradually restituted within the restitution programmes (Witkowski et al. 2001, 2002, 2004a,b, Blachuta et al. 2010b).

\section{Alien species}

Nineteen alien fish species occur in inland waters of Poland (Grabowska et al. 2008, 2010). Ten introduced species were recorded from the waters of Wroclaw (Cyprinus carpio, Carassius gibelio, Ctenopharyngodon idella, Hypophthalmichthys molitrix, Aristichthys nobilis, Pseudorasbora parva, Piaractus brachypomus, Ameiurus nebulosus, Oncorhynchus mykiss, Hucho hucho), most of them introduced on purpose.

\section{Stocking and angling catches}

In 1999-2003 and 2005-2010 the PZW, Wroclaw Branch - the fishery manager in the area - released into the Odra in its Wrocław section ca. $1.4 \mathrm{mln}$ individuals of summer and autumn yearlings and 4.5 tons of various categories (fish aged one and two years) of stocking material of eight valuable and disappearing fish species (Table 4).

Table 4. Stocking with various fish assortments (individuals and $\mathrm{kg}$ ) of the Wroclaw section of Odra (fishing district no. 4 in 2005 - 2010; $1_{1}$ - summer yearlings, $1_{j}$ - autumn yearlings, 2 - second year fish

\begin{tabular}{|c|c|c|c|c|c|}
\hline No. & Species & $1_{\mathfrak{j}}+1_{1}$ (indiv.) & $1_{1}(\mathrm{~kg})$ & $1_{\mathrm{j}}(\mathrm{kg})$ & $2(\mathrm{~kg})$ \\
\hline 1. & Aspius aspius & 41720 & - & - & - \\
\hline 2. & Barbus barbus & 55520 & - & - & - \\
\hline 3. & Leuciscus idus & 1200 & 100 & - & 600 \\
\hline 4. & Esox lucius & - & 231 & 3000 & - \\
\hline 5. & Silurus glanis & 1024 & - & - & 600 \\
\hline 6. & Chondrostoma nasus & 139800 & - & - & - \\
\hline 7. & Lota lota & 32520 & - & - & - \\
\hline 8. & Sander lucioperca & 36000 & - & - & - \\
\hline & $\Sigma$ & 307784 & 331 & 3000 & 1200 \\
\hline
\end{tabular}

Analysis of registers of angling catches showed that in 2005-2008 in the Wroclaw section of the Odra anglers caught 69481 fish representing 25 species. The most often caught species was common bream - 31.79\%, followed by roach/rudd $-29.90 \%$, perch $-16.60 \%$, dace/ide/chub $-3.55 \%$, pike-perch and pike $-2.43 \%$, carp $-0.94 \%$, asp $-62 \%$, tench $-0.58 \%$, gibel $-0.50 \%$, crucian carp $-0.34 \%$, wels $-0.25 \%$, grass carp $-0.08 \%$, eel $-0.06 \%$, burbot $0.04 \%$, vimba $-0.04 \%$, nase $-0.03 \%$, barbel $-0.02 \%$ and brown trout, rainbow trout, bighead and silver carp $-0.01 \%$ each. The effects of catches in this section of the river included 7535 fish (9.78\%) ("others" in Table 5) of about a dozen remaning species, caught in the same river section, with a percentage less than 0.01 .

In the same period the catches from the city reservoirs amounted to a total of 8824 fish, and 7382 specimens $(84.0 \%)$ represented 15 species which constituted the following proportion: roach $/$ rudd $-40.02 \%$, carp $-14.73 \%$, common bream $-11.01 \%$, perch $-6.98 \%$, pike $-2.45 \%$, rainbow trout $-2.25 \%$, gibel $-1.95 \%$, tench $-1.50 \%$, crucian carp $-1.16 \%$, pike-perch $-0.75 \%$, eel $-0.64 \%$, ide $-0.47 \%$, grass carp $-0.09 \%$ and wels $-0.03 \%$ (Table 5 ). Further 13 species, represented by single specimens, constituted about $16 \%$. 
Table 5. Size of angling catches and proportion of individual fish species in the Wroctaw section of Odra River (fishing district no. 4, and city reservoirs in 2005-2008.

\begin{tabular}{|c|c|c|c|c|c|}
\hline \multirow{2}{*}{ No. } & \multirow{2}{*}{ Species } & \multicolumn{2}{|c|}{ Odra River } & \multicolumn{2}{|c|}{ City reservoirs } \\
\hline & & No & $\%$ & No & $\%$ \\
\hline 1 & Abramis brama & 24481 & 31.79 & 994 & 11.01 \\
\hline & Rutilus rutilus and Scardinius & & & & \\
\hline 2 & erythrophatlmus & 23025 & 29.90 & 3613 & 40.02 \\
\hline 3 & Percafluviatilis & 12787 & 16.60 & 630 & 6.98 \\
\hline 4 & Leuciscus idus & 2536 & 3.55 & 43 & 0.47 \\
\hline 5 & Sander lucioperca & 1875 & 2.43 & 68 & 0.75 \\
\hline 6 & Esox lucius & 1874 & 2.43 & 221 & 2.45 \\
\hline 7 & Cyprinus carpio & 703 & 0.91 & 1329 & 14.73 \\
\hline 8 & Aspius aspius & 479 & 0.62 & - & - \\
\hline 9 & Tinca tinca & 449 & 0.58 & 135 & 1.50 \\
\hline 10 & Carassius gibelio & 386 & 0.50 & 176 & 1.95 \\
\hline 11 & Carassius carassius & 263 & 0.34 & 105 & 1.16 \\
\hline 12 & Silurus glanis & 194 & 0.25 & 3 & 0.03 \\
\hline 13 & Ctenopharyngodon idella & 62 & 0.08 & 7 & 0.09 \\
\hline 14 & Anguilla anguilla & 46 & 0.06 & 58 & 0.64 \\
\hline 15 & Lota lota & 46 & 0.06 & - & - \\
\hline 16 & Vimbavimba & 27 & 0.04 & - & - \\
\hline 17 & Chondrostoma nasus & 23 & 0.03 & - & - \\
\hline 18 & Barbus barbus & 19 & 0.02 & - & - \\
\hline & Aristichthys nobilis and & & & & \\
\hline 19 & Hypophthalmichthys molitrix & 6 & 0.01 & - & - \\
\hline 20 & Oncorhynchus mykiss & 9 & 0.01 & 203 & 2.25 \\
\hline 21 & Salmo trutta m. fario & 6 & 0.01 & - & - \\
\hline 22 & Other species & 7535 & 9.78 & 1442 & 15.97 \\
\hline & $\sum$ & 77015 & 100.0 & 9027 & 100.0 \\
\hline
\end{tabular}

\section{REVIEW OF SPECIES}

Petromyzontidae - Lampreys

\section{Brook lamprey - Lampetra planeri (Bloch, 1784)}

Locality: $12 . \mathrm{C}=2.3$.

Single specimens of brook lamprey were recorded in 2002-2005 during the studies and control catches in the Dobra River (tributary to Widawa) in the environs of Pruszowice and Zakrzów (Wroclaw - Psie Pole).

\section{Acipenseridae - Sturgeons}

\section{Baltic sturgeon - Acipenser oxirynchus Mitchell, 1815}

Localities: $10-12,28 . \mathrm{C}=7.0$.

In 1965 the species became extinct in Poland (Kolman 2007), and much earlier in the middle Odra system (Pax 1925). According to the latter author at about half of the $19^{\text {th }} \mathrm{c}$. it was still caught in the Olawa River, and the last sturgeons were caught in the Odra in Wroclaw in 1905 and near Malczyce in 1920. Within the restitution programme for anadromous fishes in the middle Odra basin the Fish Breeding Center of the PZW , Szczodre” near Wroclaw breeds sturgeon to stock selected tributaries of the Odra (Barycz, Widawa) (Witkowski et al. 2004a). 
Anguillidae - Freshwater Eels

Eel - Anguilla anguilla (Linnaeus, 1758)

Localities: $5,7,11-12,15,17,18,20,23-29 . \mathrm{C}=34.9$.

It is rarely recorded in the Wroclaw waters. The specimens caught come from stocking by the PZW, private owners of water bodies and some institutions - Wroclaw Waterworks (MPWiK-Wroclaw). A part of the individuals from the mouth section of Widawa are no doubt fugitives from fish ponds (Szczodre, Domaszczyn, Zakrzów) of the Fish Breeding Center of the PZW ,Szczodre" which is located in the suburbs of Wroclaw and fed by the waters of the Dobra River (tributary to the Widawa) (Witkowski \& Paszkowski 2002, Witkowski et al. 2007a).

Cyprinidae - Minnows (=Carps)

\section{Barbel - Barbus barbus (Linnaeus, 1758)}

Localities: $8,11-12,15,18,20,21,26-29 . \mathrm{C}=27.9$.

Till recently the barbel was on the brink of extinction in the running waters of Wroclaw, as a result of considerable pollution of the waters of Odra and some of its tributaries. At the beginning of the 1990s it was recorded only in the Olawa, which it reached from the Nysa Klodzka (where locally it is very abundant - Kotusz et al. 2009) via the canal of Psarski Potok (Witkowski et al. 1992a,b), whose purpose is to constantly feed the waters of Olawa, used by the Wroclaw Waterworks (MPWiK-Wrocław).

At present, restitution of anadromous and rheophilous fishes in the middle Odra basin is conducted within the programme „Pomoc dla Odry - 2006” (Witkowski et al. 2002). In 19992003 the PZW released over 55 thousand summer fingerlings of the species into the Odra (Table 4), hence the barbel is increasingly often caught by anglers (Table 5). The species is more abundant in rapid sections of the Wroclaw Odra - below dams, weirs and in narrow canals (e.g. storm canal - Bartoszowice weir - Warszawski Bridge) and mouth sections of the Bystrzyca.

\section{Carp - Cyprinus carpio Linnaeus, 1758}

Localities: 3, 5-7, 10-12, 17-32, 34-35,37-39, 41-43. $\mathrm{C}=72.1$.

Because of great interest of anglers, artificial reservoirs within the city (park ponds, gravel and clay pits, ponds in water intake areas) are very often stocked with carp. Every year the PZW releases ca. 6 tons of carp into these reservoirs. Single individuals of carp found in open waters are mainly fugitives from the numerous fish farms in Silesia (Witkowski \& Paszkowski 2002) or specimens which got out of the ponds during major floods.

\section{Crucian carp - Carassius carassius (Linnaeus, 1758)}

Localities: $3,5-7,9,12,16-28,30-35,37-39,41-43 . \mathrm{C}=69.8$.

In open waters the crucian carp is usually represented by single specimens. It is much more abundant in its typical habitats - park ponds and clay pits.

\section{Giebel - Carassius gibelio (Bloch, 1783)}

Localities: $3,5-7,9,12-13,17-39,41-43 . \mathrm{C}=74.4$.

It is one of the most common species recorded in Wroclaw, it occurs mainly in stagnant waters such as park ponds and clay pits used by anglers. In such reservoirs it most often occurs in masses, forming usually mono-species communities, for example in a pond of 0.5 ha at Anielewicza Street, in October 2010 , ca. $600 \mathrm{~kg}$ fish of this species were caught. Single specimens are usually encountered in the running waters of Wroclaw. 


\section{Grass carp - Ctenopharyngodon idella (Valenciennes, 1814)}

Localities: 5, 7, 10-12, 17-21, 23-29, 31-32, 35, 37, 38, 42. C = 53.5.

In open waters it is rarely recorded and not abundant. In the Odra anglers caught grass carp most often and in large numbers after major floods (e.g. 1997 and 2009) which may suggest that the specimens were fugitives from damaged fish ponds.

PZW-managed clay pits and gravel pits are constantly stocked with the species in order to increase their angling attractiveness or remove the excess of vascular vegetation.

\section{Gudgeon - Gobio gobio (Linnaeus, 1758)}

Localities: $1-4,6,8-13,15-18,20-29,42 . \mathrm{C}=60.5$.

The gudgeon is abundant in the whole Wroclaw section of the Odra and in other rivers joining it in the region. It was recorded from the lower section of Bystrzyca $(0.22$ indiv. $/ 100$ $\mathrm{m}^{2}$ ), Widawa $\left(2.1-2.6\right.$ indiv. $\left./ 100 \mathrm{~m}^{2}\right)$, and its mass occurrence was observed in the mouth section of Ślęza (108.8-624.0 indiv./100 m²) (Witkowski et al. 1991b, 1992b, Kotusz et al. 1996). The species was not recorded from stagnant waters.

White-fin gudgeon - Gobio (Romanogobio) albipinnatus (Lukasch, 1933)

Localities: $16-18,20,21,23,26-29 . \mathrm{C}=23.2$.

It is one of the rarest species in Poland (Witkowski et al. 2007b, 2009). In the Odra proper it is fairly abundant in the whole Wroclaw secion and in the canals, preferring deep parts in the current (Blachuta et al. 1994).

\section{Tench - Tinca tinca (Linnaeus, 1758)}

Localities: 1-7, 9-12, 17-35, 37-43. C = 83.7.

In the running waters of Wroclaw the species is not abundant. Exceptions are the lower, mouth section of the Olawa (,Kapielisko Olawka”) and Widawa from the mouth of the Dobra River, which the species penetrates constantly from the Fish Breeding Center "Szczodre" (Witkowski \& Paszowski 2002). The tench is fairly abundant in the ponds of the water intake area of Wroclaw, and every year park ponds are stocked with it as a biomanipulation tool to control mosquito larvae.

\section{Bitterling - Rhodeus sericeus (Pallas, 1776)}

Localities: $1-2,4,5,7,9-13,17-20,22-28,32,37-39 . \mathrm{C}=55.8$.

The bitterling is one of the less frequent species in Wroclaw. Till now it was recorded from the Odra in the section from Opatowicka island till the mouth of Olawa, and in the mouth section of the latter river where the density was estimated as $0.2-0.4 \mathrm{indiv} . / 100 \mathrm{~m}^{2}$. Besides, it occurs in the lower section of Ślęża (Witkowski et al. 1992b).

\section{Common bream - Abramis brama (Linnaeus, 1758)}

Localities: $2-7,9,12,14-15,17-29,31,35,37-39,41 . \mathrm{C}=69.7$.

The species is among the most abundant and frequent in the Wroclaw section of the Odra, both in the main bed and in the canals. In the winter it is caught in its wintering grounds which are usually deep, slow-flowing or stagnant parts of the river (e.g. barge winter harbour in Osobowice). During spawning the bream gathers in masses in the mouth sections of the Odra tributaries (Bystrzyca, Olawa, Widawa). Besides, it is often observed in PZW-managed urban reservoirs (clay and gravel pits).

Silver bream - Abramis bjoerkna (Linnaeus, 1758)

Localities: 2-5, 7, 9-11, 13-15, 17-29, 31, 35, 37-41. C = 74.4. 
The silver bream is abundant both in the Wroclaw Odra and in its canals. It is also abundant in mouth sections of the Widawa, Bystrzyca and Olawa (Witkowski et al. (1991b, 1992a,b, Kotusz et al. 1996). The species is often encountered in PZW-managed larger clay pits and gravel pits (Maślice, Pilczyce, Żerniki).

\section{Blue bream - Abramis ballerus (Linnaeus, 1758)}

Localities: 4, 5, 7, 11, 17-18, 20, 23-29, 31. C = 51.2.

It is the rarest species of the genus Abramis in the Odra. It is regularly observed in the Odra in the section from Opatowicka island to the Rędzin lock, both in the main bed and canals, and in barge winter harbour of Żegluga Wroclawska (Blachuta 1993). Besides, it was recorded from the lower section of Olawa (Witkowski et al. 1992b). In the last 40 years the upper limit of its distribution in the Odra shifted to the middle section of the river (within the city boundaries) (Witkowski et al. 2007b).

\section{Vimba - Vimba vimba (Linnaeus, 1758)}

Locality: $11-12,14-15,19-2123,26-28 . \mathrm{C}=25.6$.

Till recently the species was regarded as extinct in the middle Odra (Witkowski et al. 2000, Kotusz et al. 2001), though it had been earlier mentioned by Pax (1925) from the Wroclaw section of Bystrzyca. Restitution of the species in the whole Odra system was attempted, based on a vestigial population surviving in the Barycz (Kleszcz et al. 2001, Witkowski et al. 2001, 2002, 2004a,b). In 2000-2003 the PZW stocked (ca. 0,5 mln yearlings) the middle Odra basin, including the Wroclaw tributaries to the river (Bystrzyca, Widawa). At present the vimba returning from the sea to spawn reaches the open waters of Wroclaw where it is sporadically caught by anglers in the Odra and mouth sections of some of its tributaries (Blachuta et al. 2010b).

Roach - Rutilus rutilus (Linnaeus, 1758)

Localities: $1-31,34,35,37-42 . \mathrm{C}=90.7$.

The roach is the most abundant and most frequent species in the waters of Wroclaw. It is present both in the Odra with its canals and tributaries, and in the city reservoirs (ponds, clay and gravel pits etc.). In the autumn and winter it gathers in masses in slow-flowing or stagnant parts of the Odra and its artificial coves (e.g. barge winter harbour of Żegluga Wroclawska, Wroclaw-Osobowice).

\section{Rudd - Scardinius erythrophthalmus (Linnaeus, 1758)}

Localities: $1,2,4-7,9-15,17-28,30-35,34,35,37-43 . \mathrm{C}=88.4$.

The species is not abundant in running waters, though frequently recorded, among others, in the Odra, lower section of Olawa and Ślęza where its density was 3.7 indiv. $/ 100 \mathrm{~m}^{2}$ (Witkowski et al. 1992b). It is distinctly more abundant and more frequent in clay and gravel pits, in city and park ponds where it is introduced as fry to control mosquito larvae.

\section{Nase - Chondrostoma nasus (Linnaeus, 1758)}

Localities: $10-12,14-15,18,20-23,25-29 . \mathrm{C}=34.9$.

The nase is not abundant and very rare in the running waters of Wroclaw. According to Kaluza (1815), Gloger (1833) and Schikora (1896) (after Pax 1925) the species was once common in the Odra in the environs of Wroclaw.

Within the programme of restitution of anadromous and rheophilous fishes, in 1999-2010 ca. $0.6 \mathrm{mln}$ fry were released into the Odra and its tributaries. At present nase is caught in the Wroclaw section of the Odra and its fast-flowing canals. Besides, it is encounterd in the lower 
sections of Bystrzyca and Widawa with its tributary Dobra (Witkowski \& Paszkowski 2002, Blachuta et al. 2010b).

\section{Silver carp - Hypophthalmichthys molitrix (Valenciennes, 1844)}

Locality: $17-18,20-29,38 . \mathrm{C}=30.2$.

Silver carp is rarely encountered in the open waters of Wroclaw. In the angling catches in the Odra there is a considerable increase in the number of silver carp after major floods in the Odra basin (e.g. 1997, 2009), which may indicate that these individuals are fugitives from ponds, since the PZW does not stock rivers with this species. Only a small quantity of stocking material is introduced into clay and gravel pits within the city to make them more attractive for anglers.

\section{Bighead - Aristichthys nobilis (Valenciennes, 1844)}

Localities: $18,20,21,23,25-27 . \mathrm{C}=16.3$.

The bighead carp is rarely recorded in the open waters of Wroclaw. Like the preceding species, its numbers in the angling catches increase after major floods (e.g. 1997 and 2009), indicating that the fish are fugitives from fish ponds. Only a small quantity of stocking material is introduced into clay and gravel pits within the city to make them more attractive for anglers.

\section{Asp - Aspius aspius (Linnaeus, 1758)}

Localities: $4-7,10-12,14,15,17-29 . \mathrm{C}=51.2$.

In Wroclaw the species occurs only in running waters - in the Odra, its canals and mouth section of Olawa. The asp is among the more abundant predators in the main current of the river (Witkowski et al. 2007b), hence in the last decade the stocking is maintained at a low level (ca. 42 thousand of yearlings).

\section{Sunbleak - Leucaspius delineatus (Heckel, 1843)}

Localities: $2,5,7,9,11-13,17-20,23-26,28,31-35,37-41$. $\mathrm{C}=62.8$.

The species was recorded from the stagnant and slow-flowing parts of the rivers. Considerable numbers of sunbleak are observed every year (October-November) in the Widawa below the mouth of Dobra, which corresponds to the time of leaving the ponds of the Fish Breeding Center "Szczodre” (Witkowski \& Paszkowski 2002). The species is also encountered in park ponds and city ponds where it has been introduced for a few years in order to control mosquito larvae. The occurrence of the sunbleak in many oxbows in the environs of Wrocław, in the Odra and Olawa, was mentioned by Pax (1925).

\section{Swamp minnow - Eupallasella percnurus (Pallas, 1811)}

Localities: $32,33 . \mathrm{C}=4.6$.

This species, protected in Poland, was experimentally introduced in a pond in the Botanic Garden of Wroclaw University (Kusznierz 1998, Kusznierz et al. 2002), from where it penetrated to a city pool in the Nowowiejska Street, connected with the pond by an underground canal. The population is composed of individuals originating from a few localities in Polesie Lubelskie (SE Poland).

\section{Dace - Leuciscus leuciscus (Linnaeus, 1758)}

Localities: $2,8-18,20-23,26-29 . \mathrm{C}=46.5$.

The dace is frequently and abundatly encountered in lotic sections of the Odra and its canals within the whole city of Wroclaw. Besides, the species occurs in the lower section of Widawa (Blachuta 2000). 


\section{Chub - Leuciscus cephalus (Linnaeus, 1758)}

Localities: 1-3, 6-18, 20-23, 24-29, 34, 37-39. C =67.4.

The chub occurs abundantly in the whole Wroclaw section of the Odra; in some fastflowing canals it is among the dominants (storm canal from Bartoszowice weir to Zalesie). It is also abundant in the lower sections of Widawa and Ślęza - 0.2-0.5 indiv./100 m2 (Witkowski et al. 1991b, 1992b).

\section{Ide - Leuciscus idus (Linnaeus, 1758)}

Localities: 2, 5-12, 14-29, 32-34, 37, 40, 42-43. C $=72.1$.

Within Wroclaw the species is the most abundant member of the genus Leuciscus. It occurs in the Odra, its canals, as well as in the Widawa and Bystrzyca where it is among subdominants, reaching densities of 0.3-1.9 indiv./100 m2 (Witkowski et al. 1991b, Kotusz et al. 1996).

The ide, and especially its coloured (xanthoric form) „orpha” is often released into park ponds and the city moat as an ornamental fish.

\section{Bleak - Alburnus alburnus (Linnaeus, 1758)}

Localities: $2-11,13-29,37 . \mathrm{C}=65.1$.

The bleak is a common and very abundant species occurring in the whole Wroclaw section of the Odra and in its canals; in the lower sections of Bystrzyca, Widawa and Olawa its density was 0.6-2.9 indiv./100 m2 (Witkowski et al. 1991b, 1992b, Kotusz et al. 1996). It occurs also in larger clay and gravel pits.

\section{Topmouth gudgeon - Pseudorasbora parva (Temminck \& Schlegel, 1846)}

Localities: $10-12,32,33,41,43 . \mathrm{C}=16.3$.

This east Asian species was introduced in many fish ponds in Poland with carp stocking material; from there it quickly invaded open waters (Witkowski 2009). At present it occurs in the lower section of Widawa and its tributary Dobra, as well as in the pond of the Botanic Garden and the city moat.

Cobitidae - Loaches

Spined loach - Cobitis taenia Linnaeus, 1758 and spined loach complex - Cobitis complex

Localities: $3,8,16,18,28 . \mathrm{C}=16.3$.

Individuals of pure $C$. taenia (Odra near Ratowice) and parthenogenic hybrids with danubian loach $C$. elongatoides (Kotusz unpubl. data) were recorded from the Wroclaw section of the Odra. Sexual and asexual forms are morphologically very similar, and their identification requires genetic methods (Boron 2004, Kotusz 2008). The fishes of the so called "Cobitis complex" in the Odra basin (Boron 2004) were recorded in the Odra, some of its canals, lower sections of Olawa and Widawa.

\section{Golden loach - Sabanejewia baltica (Witkowski, 1994)}

Localities: $8,9 . \mathrm{C}=4.6$.

The species was found only in the lower section of Widawa, in the environs of Wilczyce and Kielczów (Wroclaw - Psie Pole) (Witkowski et al. 1990, 1991b). The latter locality is the type locality of this recently described species (Witkowski 1994a).

Mud loach - Misgurnus fossilis (Linnaeus, 1758)

Localities: $2,5,7,10-12,17-20,24-28,34,41$. C $=39.5$. 
The mud loach is one of the rare and infrequent species in the city of Wroclaw. It was recorded from the lower section of Bystrzyca (Kotusz et al. 1996) and Olawa (Witkowski et al. 2000), including the ponds of MPWiK ,Na Grobli”.

\section{Balitoridae - River loaches}

\section{Stone loach - Barbatula barbatula (Linnaeus, 1758)}

Localities: $1-3,9,12-15,17,18,20-21,23,26-28$. $\mathrm{C}=37.2$.

The species is among the rare and unabundant fishes in the region of Wroclaw. It is abundant only in the lower section of Slęza where its density ranges from 4.3 to 9.2 indiv./100 $\mathrm{m} 2$ (Witkowski et al. 1992b); the density is much smaller in the Widawa (environs of Wilczyce -0.6 indiv./100m2) (Witkowski et al. 1991b).

\section{Characidae - Characins}

\section{Pirapitinga (red pacu) - Piaractus brachypomus (Cuvier, 1818)}

Localities: $(37,39)$ ? $\mathrm{C}=4.6$.

Two individuals $(31.8$ and $26.6 \mathrm{~cm} \mathrm{Tl})$ of this exotic species were caught by anglers $(07$ and 22. 08. 2002) in two Wroclaw clay pits in the districts Pilczyce and Żerniki (Witkowski \& Kotusz 2003). The species is sold in pet shops as piranha (Serrasalmo nattereri), and once they reach a considerable size in the aquarium, they are often released into the nearest water body. Similar cases were reported elsewhere in Poland, and also in other countries of Europe and Near East. Both specimens are kept in the collection of the Natural History Museum, Wroclaw University.

\section{Ictaluridae - North American Freshwater Catfishes}

\section{Brown bullhead - Ameiurus nebulosus (Le Sueur, 1819)}

Localities: 4-9, 14-15, '17-29, 31, 34, 35, 37-42. C $=67.4$.

The brown bullhead was introduced in the Odra system in 1885. At the beginning of the 20 th c. it was already common in the environs of Wroclaw (Pax 1925). At present it occurs in the lower section of Olawa (from Mokry Dwór to Rakowiec) (Witkowski et al. 1992b), and is especially abundant in the ponds of water intake area (MPWiK) fed by this river (Paduszek 2000). The species is often encountered and caught by anglers in the Odra itself, mainly in parts with slow flow, in numerous canals, branches and coves within the city.

\section{Siluridae - Eurasian Catfishes}

\section{Wels - Silurus glanis Linnaeus, 1758}

Locality: 4-7, 14-15, 17, 18, 20-29, 31, 37, 38, 40. C = 51.2.

The species is the largest predator in our waters. At the end of the 20 th $\mathrm{c}$. it was already rare in the Wroclaw section of Odra. The only and abundant population survived in the lower section of Olawa and its numerous branches within the water intake area of Wroclaw, managed by the MPWiK (Witkowski et al. 1992b). Based on this population, at the end of the 1980s the PZW attempeted breeding stocking material and restitution of the species in the middle Odra basin (Witkowski et al. 2002), where till now 1024 yearlings and $600 \mathrm{~kg}$ of fish two years old were released (Table 4). At present wels is abundant and often caught in the Odra and its canals within the city of Wroclaw. Besides, few small individuals are encountered in the Widawa below the Dobra mouth to which the species penetrates from the ponds of the Fish Breeding Center of the PZW ,Szczodre” (Witkowski \& Paszkowski 2000). 
Esocidae - Pikes

\section{Pike - Esox lucius Linnaeus, 1758}

Localities: $1-29,31,32,34-35,39-41,43 . \mathrm{C}=88.4$.

Though the pike is a popular object of angling and intense stocking of the Odra, in the Wroclaw section of the river it is not abundant (Table 1). This is associated, among other factors, with canalising the river and changes in its flow, especially during spawning, for the needs of navigation and hydro power plants, with the destruction of formerly more numerous oxbows and with the excessive angling pressure.

The species is constantly encountered in the Odra, its canals and coves and mouth sections of the Widawa, Olawa and Bystrzyca (Witkowski et al. 1991b, 1992b, Witkowski \& Paszkowski 2002, Kotusz et al. 1996). Besides it is released in considerable quantities (500 $\mathrm{kg} /$ year) into the PZW-managed clay and gravel pits as well as park ponds and city moat.

Salmonidae - Salmonids

\section{Huchen - Hucho hucho Linnaeus, 1758}

Locality (18)? $\mathrm{C}=2.3$.

Two specimens of the species (weight 9 and $7 \mathrm{~kg}$ ) were caught by anglers in 1998 and 1999 below the weir at the Opatowicka Island. In Poland the species, outside the Czarna Orawa basin, occurs also in non-autochthonous localities in the Dunajec, Poprad and San Rivers (Witkowski 2003). At the beginning of the 1990s the PZW released into the Odra in Janowice (ca. $10 \mathrm{~km}$ below the site of the catch) ca. 200 of huchen fingerlings bought from the Fish Breeding Center Łopuszna.

\section{Salmon - Salmo salar Linnaeus, 1758}

Localities: $10-12,15,18,20,23,27-28 . \mathrm{C}=20.9$.

The salmon was regularly caught near Wroclaw from the middle ages till half of the 19th c. (Schwenckfeld 1603, Kanold 1719, Gloger 1833, after Pax 1925). As a result of building of hydrotechnical construction, long-lasting overexploitation and, most of all, considerable pollution of the Odra waters, within the last few dozen years the species was very rarely encountered in the environs of Wroclaw, and every catch of a single specimen was mentioned in the local press as a sensation (Slowo Polskie 2002). After Poland joined the EU and with increasing improvement of the water quality in the Odra, the PZW started restitution of anadromous and migratory fishes in the middle Odra basin (Witkowski et al. 2002). Salmon restitution, based on stocking material from the population in the Dźwina/ Dougava River, started from the Widawa with its tributary Dobra, where in 2001-2004 47 thousand presmolts and smolts, 28 thousand summer yearlings and 32 thousand fry of the species were released (Witkowski et al. 2000, 2004a). These actions were already partly successful, since below the hydro power station in Waly Śląskie near Brzeg Dolny salmon migrating upstream are observed every year (Blachuta \& Kusznierz 1995). Regretfully, still rather few individuals reach the Wroclaw waters.

\section{Sea trout - Salmo trutta m. trutta Linnaeus, 1758}

Locality: $10-12,14,15,18,20-23,2629 . \mathrm{C}=30.8$.

Like salmon, the species in the Odra suffers because of long-lasting anthropopressure (Blachuta \& Kusznierz 1995, Witkowski et al. 2000). Till half of the 1980s only single specimens were encountered in the river below the power plant in Waly Ślasskie, and even 
fewer above this obstacle (Kalinowski 1991). The last sea trout for reproductive purposes were caught in the Odra in Wroclaw (below Bartoszowice weir) in early $1950 \mathrm{~s}$.

Sea trout restitution started with stocking a few rivers in the environs of Wroclaw (among others Strzegomka, Smortawa, Średzka Woda, Jeziorka, Widawa, Dobra), where in 1998-2003 28 thousand smolts and presmolts, 76.5 thousand summer yearlings and 545 thousand swimming fry were released (Witkowski et al. 2004c). The stocking was continued in later periods. At present the sea trout is a constant though not abundant component of the Wroclaw ichthyofauna and is sporadically caught by anglers in the storm canal of the Odra. Since 2008 sea trout spawning has been observed annually in the mouth section of Bystrzyca (Blachuta et al. 2010).

\section{Brown trout - Salmo trutta m. fario Linnaeus, 1758}

Localities: $10-12,14-15,26 . \mathrm{C}=13.9$.

In the environs of Wroclaw the brown trout is encountered mainly in the lower section of Widawa and its tributary Dobra, since in the upper section autochthonous populations of the species exist (Witkowski et al. 1991b). ). Individuals - fugitives from the Fish Breeding Center of the PZW „Szczodre” may be present (Witkowski \& Paszkowski 2002, Witkowski et al. 2007a).

\section{Rainbow trout - Oncorhynchus mykiss Walbaum, 1792}

Localities: $10-12,14,15,18,21,37 . \mathrm{C}=18.6$.

Because of the increasingly frequent farming and building of the so called recreational ponds, the species is increasingly often recorded in the waters of Wroclaw. In recent years duing angling contests a few specimens of rainbow trout were caught in the storm canal of the Odra (Biskupin). Few fugitives (from Fish Breeding Center, PZW „Szczodre”) occur in the lower section of Widawa and its tributary Dobra (Witkowski et al. 1991b, Witkowski \& Paszkowski 2002). To make the city angling sites more attractive, the PZW stocks clean and deep clay pit with the species (e.g. Pilczyce clay pit).

Gadidae - Cods

\section{Burbot - Lota lota (Linnaeus, 1758)}

Localities: $2,8-15,17,18,20-29 . \mathrm{C}=51.2$.

In a few recent decades the burbot abundance in the middle Odra basin decreased drastically because of the water pollution (Blachuta \& Kusznierz 1995). In 1997-2001 $8.5 \mathrm{mln}$. fry of the species for stocking of the middle Odra basin and Wroclaw section of the Odra were produced by the PZW Fish Breeding Center „Szczodre” (Kleszcz et al. 2002). Despite intensive stocking the species is scarce in the region of Wroclaw. Single specimens were recorded in the storm canal of the river below the Bartoszowice weir. Besides, its occurrence was noted in the lower section of Olawa, Widawa, Dobra and Bystrzyca (Witkowski et al. 1991b, 1992b, Kotusz et al. 1996, Witkowski \& Paszkowski 2002).

\section{Gasterosteidae - Sticklebacks}

\section{Stickleback - Gasterosteus aculeatus Linnaeus, 1758}

Localities: $1-2,4-7,9-15,17,1,34,35,37-39,41 . \mathrm{C}=74.4$.

It is a common and very abundant species occurring in small water courses, drainage ditches and calm coves of the Odra and its tributaries. It is especially abundant in the autumn when, during emptying of the fish ponds, large numbers of stickleback penetrate into open waters (Ślęża, Bystrzyca, Oława, Widawa with Dobra) (Witkowski et al. 1991b, 1992b, Kotusz et al. 1996). In this period the stickleback forms periodic dominance (Witkowski \& Paszkowski 2002, Witkowski et al. 2007a). The species is also found in park and city ponds, clay and gravel pits. 
Percidae - Perches

\section{Perch - Perca fluviatilis Linnaeus, 1758}

Localities: $2-31,34,35,37-41,43 . \mathrm{C}=88.4$.

At present it is the most abundant predator in the running waters of Wroclaw. It occurs both in the Odra itself, and in its canals, coves and branches, where it gathers to spend winter. The perch is also recorded from the lower section of the tributaries of the river: Widawa $-0.8-1.4$, Olawa - 0.4-0.9 and Bystrzyca - 1.1-3.4 indiv./100 $\mathrm{m}^{2}$ (Witkowski et al. 1991, 1992, Kotusz et al. 1996). The species is abundant in many clay and gravel pits in the city.

Pike-perch (sander) - Sander lucioperca (Linnaeus, 1758)

Locality: $2-7,10-15,17-18,20-29,41$. C $=62.8$.

The pike perch was mentioned by Pax (1925) and earlier authors as abundant in the Odra. Following a period of decreased abundance as a result of pollution of the Odra, the population in the Wroclaw Odra during the last about a dozen years shows an increasing tendency. In 1999-2010 the PZW released ca. 36 thousand yearlings of the species into the Wroclaw Odra. The pike perch is the most frequent large predator in the Odra, its canals, and lower section of Bystrzyca (Kotusz et al. 1996) and Olawa where its density is $1.2-2.4$ indiv. $/ 100 \mathrm{~m}^{2}$ (Witkowski et al. 1992a,b). The species was recorded from a few larger and deeper clay pits (Pilczyce, Leśnica), where it was repeatedly released by PZW.

\section{Ruff - Gymmocephalus cernuus (Linnaeus, 1758)}

Localities: $3-5,7,13,17-29,31,35,37-39,41$. C $=62.8$.

The ruff is the most abundant percid in the Odra, its canals, coves and branches. It is abundant in the lower section of Olawa (Witkowski et al. 1992b); it was also found in a few clay pits (Leśnica, Pilczyce).

Hybrids of cyprinid fishes

Leuciscus idus (Linnaeus, 1758) x Leuciscus cephalus (Linnaeus, 1758)

Locality: 22. $\mathrm{C}=2.3$

One specimen, a hybrid of ide and chub, was caught and described for the first time from the storm canal of the Odra, district Seppolno-Bartoszowice (Witkowski \& Blachuta 1989). Its appearance in the Odra was explained by the great abundance of parental species of the genus Leucicsus and their overlapping spawning period.

Alburnus alburnus (Linnaeus, 1758) x Abramis brama (Linnaeus, 1758) Abramis brama (Linnaeus, 1758) x Alburnus alburnus (Linnaeus, 1758)

Locality: 16. $\mathrm{C}=2.3$.

Of the three specimens described from the middle section of the Odra, one was caught above Wroclaw in the oxbow „Lacha Jelcz” (Blachuta \& Witkowski 1983/1984).

\section{Abramis brama (Linnaeus, 1758) x Rutilus rutilus (Linnaeus, 1758)}

Localities: $16-27 . \mathrm{C}=18.6$

It is one of the most frequently recorded hybrids within cyprinids, but rather scarce in the whole Wroclaw section of the Odra. 


\section{DISCUSSION}

Wroclaw is located in the area where the Odra is joined by more than ten smaller and larger tributaries. With the main river they form a rich natural river system within which the city is situated. The Odra, with its tributaries within Wroclaw, is at present the largest river junction in Poland. Its origin was associated with an array of hydrotechnical investments from the very beginnings of human settlement (Dziubek 1993, Bartosiewicz 1995).

At present the city ichthyofauna includes 46 species of lamprey and fish. Forty two species were recorded from the Odra itself, and 41 species from the mouth sections of its tributaries. Compared to the whole Odra system ( 54 species), these numbers are slightly smaller, since the environs of Wroclaw are devoid of most of typically montane and submontane species (Witkowski et al. 2007b). The almost identical number of species in the mouth sections of the tributaries, compared to the main river, results probably from the fact that most "Odra" fish species find favourable living conditions in them, or occur there periodically. Such features of distribution of freshwater fishes in the conditions of the present-day Europe were described in detail for the rivers of the Warta and Vistula systems (Kostrzewa 2000, Penczak et al. 2004, Pietraszewski et al. 2008, Marszal et al. 2009). When the species which disappeared at the end of the 19th and the beginning of the 20th $\mathrm{c}$. (Petromyzon marinus, Lampetra fluviatilis, Alosa alosa, Osmerus eperlanus, Pelecus cultratus) (Pax 1925, Witkowski et al. 2000, Kotusz et al. 2001) are added to the number of species recorded from the Wroclaw section of the Odra at present, the number would be only slightly smaller than the number of fish and lamprey species occurring in Poland (Rembiszewski \& Rolik 1975, Witkowski et al. 2004a, 2007b, 2009).

Till recently, studies on the ichthyofauna of the rivers and reservoris of large cities were few and fragmentary (Bieniarz \& Epler 1972, Witkowski 1973, Epler \& Bieniarz 1974, Radwan et al. 1988, Jarzynowa et al. 1990). Besides, compared to Wroclaw, they were conducted in agglomerations of distinctly poorer river systems (Kruk et al. 2003, 2005, Stani 2005, Rechulicz 2008, Galicka et al. 2011, Marszal et al. 2011) or within more limited areas - Poznań and Warsaw (Andrzejewski \& Mastyński 2006, Wiśniewolski \& Ligięza 2011). In recent years also the fish fauna of Olsztyn was studied, especially of the lakes situated within the city (Kapusta et al. 2010, Boron, Szlachciak 2011). Literature review shows that the ichthyofauna was thoroughly discussed only in the case of Kraków. Włodek \& Skóra (1993) presented the current state of the ichthyofauna and its changes in the Cracow section of the Vistula during the preceding 100 years; the industrial development and consequent pollution of the river and its tributaries in the upper section caused loss of an increasing number of fish species.

The comparison with the ichthyofauna of other cities located on large rivers shows that the fish fauna of Wroclaw (total of 46 species, 42 in the Odra) is very rich. The respective numbers for other cities are: Cracow - Vistula R. -17 (half of the 19th c. - 26, second half of the 19th c. - 23) (Włodek \& Skóra 1993), Poznań - Warta R. - 28 (Andrzejewski \& Mastyński 2006) and Warsaw - Vistula R. with city reservoirs - 40 (Wiśniewolski \& Ligięza 2011). The ichthyofauna of Olsztyn shows a considerable species richness (39 species) (Kapusta et al. 2010, Boroń, Szlachciak 2011). The city holds numerous lakes of various trophic level (most often eutrophic) which prevail over the rivers, hence the ichthyofauna, compared to those of other cities, includes several typically lacustrine species (Salmo trutta m. lacustris, Coregonus albula, C. lavaretus, Osmerus eperlanus).

It should be emphasised that the species richness and diversity of ecological guilds forming the ichthyofauna of the Odra indicate the still largely preserved habitat diversity of the river and mouth sections of its tributaries. The composition and abundance of the ichthyofauna of the Wroclaw Odra is no doubt affected by the considerable number of 
oxbows and natural branches which are preserved over considerable distance below and above the city. These waters play an important part in the fish life cycle, including obligatorily fluviatile fishes. They often constitute spawning, feeding and wintering grounds. Preserving these waters and maintaining constant connections with the main river is necessary for the proper functoning of the whole ecosystem (Holčik 1972, Holčik et al. 1976, Witkowski 1984a,b, 1994b, Welcomme1985, Penczak et al. 2000, 2003, Witkowski \& Wiśniewolski 2005).

The ichthyofauna of the Wroclaw section of Odra is dominated by ubiquitous species. The fairly even distribution of individual species indicates their considerable tolerance of habitat conditions which was repeatedly confirmed by ichthyofaunistic studies of other large canalised and regulated European rivers (Oberdorff \& Hughes 1992, Schiemer \& Wieser 1992, Wolter 2001, Wolter \& Vilcinskas 1997, Wolter et al. 2000, Penczak \& Kruk 2004). The dominance of two reproductive guilds in the Odra: phytophiles (16 species) and phytolithophiles (7), is the effect of earlier disappearance of some lithophilous species as a result of the river's transformations (regulation, canalisation) (Boët et al. 1999, Penczak et al. 1999, Kruk et al. 2001) and, till recently, also considerable pollution (Dubicki \& Florczyk-Gołowin 1999, Kruk et al. 2000, Kruk \& Przybylski 2005).

The distinct dominance (the greatest abundance and constancy indices) of two species: roach and perch, is usually regarded as indicating degradation of aquatic environment and disappearance of obligatorily fluviatile species (Błachuta, \& Witkowski 1997, Wolter \& Vilcinskas 1997, Backiel et al. 2000, Penczak et al. 2004, Pietraszewski et al. 2008). This was confirmed also in the analysed section of the Odra.

It is difficult to present an exact characteristics of the ichthyofauna of the city reservoirs. They are not directly connected with the Wroclaw rivers, and their species composition is shaped (often even for only one angling season) by stocking, most often accidental and using species which do not agree with the reservoir character (rainbow trout, pike-perch, eel, wels, silver carp, grass carp). For this reason winter and even summer deaths resulting from oxygen deficit occur there (Guziur \& Woźniak 2006).

The ten species most often caught in the Odra: common bream, roach, perch, ide, chub, dace, pike-perch, pike and carp, are also the most frequently and abundantly represented in the ichthyofauna of the Wroclaw Odra (Tables 1, 2, 4), like in other large Central European rivers (Wiśniewolski et al. 2001,Wiśniewolski \& Ligięza 2011, Wolter 2001, Wolter et al. 1999, 2000). The greatest angling pressure in the Odra is directed at the three dominant species: common bream, roach and perch whose catches reach $80 \%$, while the proportion of predators is only 5.7\%. According to Wolos \& Mickiewicz (2001) this may indicate an unsatisfactory state of the environment. Wolos (1999) and Wolos \& Mickiewicz (2001) maintain that increased catches of the three fish species by anglers have a favourable effect on the structure of the river ichthyofauna which is also true of the Odra (Blachuta \& Witkowski 1997).

\section{ACKNOWLEDGEMENTS}

We are grateful to the fishing staff of the PZW Fish Breeding Center „Szczodre” for their many-year technical help during the studies. Our thanks go to Mr. Sebastian Kleszcz, M. Sc., Eng. for preparing angling registers for statistical analysis. The help of a large group of Wroclaw anglers, especially Mr. Kazimierz Jucha and Mr. Jan Heksel who constantly provided us with valuable information on very rarely observed fish species in the Odra, is gratefully acknowledged. The paper benefited from valuable critical comments and suggestions of the two anonymous Referees. 


\section{REFERENCES}

ANDRzejewsKi W., MAstyński J. 2006. In: K A. (ed.), Przyroda miasta Poznania: www. salamandra.sylaba.pl/przyrodapoznania

BACKIEL T. \& PENCZAK T. 1989. The fish and fisheries in the Vistula River and its tributary, the Pilica River. In: Dogde D. P. (ed.), Proceedings of the International Large River Symposium, Honey Harbour, Ontario, Canada, pp. 488-503. Canadian Special Publcation Fisheries and Aquatic Sciences.

BACKIEL T., WIŚNIEWOLSKI W., BORZECKA I., BURAS P., SZLAKOWSKI J. \& WOŹNIEWSKI M. 2000. Fish assemblages in semi-natural and regulated large river stretches. Polskie Archiwum Hydrobiologii 47: 29-44.

BALON E. K. 1975. Reproductive guilds of fishes - a proposal and definition. Journal of the Fisheries Research Board of Canada 32: 821-864.

BARTOSIEWICZ S. 1995. Existing and designated technical facilities on the Oder River. In: JANKOWSKI W. \& ŚwIERKowsz K. (eds), Oder as an Ecological Corridor. State - Functioning - Threats. Fundation IUCN Poland, pp. 67-76. Warszawa. [In Polish with English abstract]

BIENIARZ K. \& EPLER P. 1972. Ichthyofauna of certain rivers in Southern Poland. Acta Hydrobiologica 14: 415-444.

B£ACHUTA J. 1993. Morphological characteristics of blue bream Abramis ballerus (L.) (Pisces, Cyprinidae) from the middle Odra River. Acta Universitatis Wratislaviensis, Prace Zoologiczne 26: 121-131. [In Polish with English abstract]

Bє ACHUTA J. 2000. O konieczności odbudowy populacji karpiowatych ryb prądolubnych w dorzeczu górnej i środkowej Odry. In: JAKUCEWICZ H. (ed.), Karpiowate ryby reofilne, pp. 33-44.. Wydawnictwo PZW, Warszawa.

B£.ACHUTA J., KoTUSZ J. \& WITKOWSKI A. 1994. Whitefin gudegon, Gobio albipinnatus Lukasch, 1933 (Cyprinidae) in the Odra River basin. Przegląd Zoloogiczny38: 309-315. [In Polish with English abstract]

BE.ACHUTA J. \& KUSZNIERZ J. 1995. Oder river as ecological corridor - an ichthyological analysis. In: JANKOWSKI W. \& ŚWERKOWSZ K. (eds), Oder as an Ecological Corridor. State - Functioning - Threats. Fundation IUCN Poland, pp. 100-115. Warszawa. [In Polish with English abstract]

Beachuta J., PictŃsKa-Faetrnowicz J., Czoch K., Kulesza K., 2010a. Abiotyczne typy wód płynących w Polsce. Gospodarka Wodna, 5: 181-191.

BE.ACHUTA J., ROSA J., WIŚNIEWOLSKI W. \& ZGRABCZYŃSKI J. (eds) 2010b. Ocena potrzeb i priorytetów udrażniania ciagłości morfologicznej rzek w kontekście osiagnięcia dobrego stanu i potencjału części wód w Polsce. Publisher Krajowy Zarząd Gospodarki Wodnej w Warszawie, Warszawa, 56 pp.

BEACHUTA J. \& WITKOWSKI A. 1983/1984. Natural hybrids Alburnus alburnus (L.) x Rutilus rutilus (L.), Alburnus alburnus (L.) x Blicca bjoerkna (L.) and Alburmus alburmus (L.) x Abramis brama (L.) from the Oder river. Acta Hydrobiologica 25/26: 189-203.

BEACHUTA J. \& WITKOWSKI A. 1997. Problemy gospodarki wędkarskiej w rzekach. In: BACKIEL T. (ed.), Wędkarstwo w ochronie wód i rybostanów, pp. 11-28. Wydawnictwo Polskiego Związu WędkarskiegoWarszawa.

BOËT P., BELlLARD J., BERREBI-dit-THOAMS R. \& TALES E. 1999. Mutiple human impacts y the City of Paris on fish communications in the Seine river basin, France. Hydrobiologia 410: 59-68

Boron A. 2004. Loaches of the genus Cobitis (Pisces, Cobitidae) distributed in the Oder and Vistula River basins. Archives of Polish Fisheries 12 (supl. 2): 159-166. [In Polish with English abstract]

Boroń A., SZlachCIAK J. 2011. Ichthyofauna of Olsztyn. In: JANKUn M., Furgala-SELEZniow G., WożNIAK M. \& WIŚNIEWSKA A.M. (eds), Water biodiversiy assessment and protection. Faculty of Environmental Protection and Fisheries, pp. 179-189. University of Warmia and Mazury, Olsztyn, Poland.

CzaRNECKA H. (ed.) 2005. Atlas podziału hydrograficznego Polski. Część 2. Zestawienia zlewni. Wydawnictwa IMGW, Warszawa, $562 \mathrm{pp}$.

CZERWIŃSKI J. 2000. Wrocław - Przewodnik. Wydawnictwo Kartograficzne - EKO-GRAF, Spólka z o.o., Wrocław, $264 \mathrm{pp}$.

DEMBńSKA. M. 1963. Konsumpcja żywnościowa w Polsce średniowiecznej. Zakład Narodowy im. Ossolińskich, Wroclaw, 52pp.

DUBICKI A. \& FLORCZYK-GOLOWIN H. 1999. Program poprawy czystości wód rzeki Odry i jej dorzecza. In: Materiały V Konferencji Naukowo-Technicznej"Problemy oczyszczania ścieków i ochrony wód dorzecza Odry", Szklarska Poręba, 22-23.06.1999, pp. 1-13.

DZIUBEK A. M. (ed.) 1993. Gospodarka zasobami wodnymi dorzecza górnej i środkowej Odry. Regionalny Zarząd Gospodarki Wodnej we Wroclawiu, Wrocław. $195 \mathrm{pp}$

Dz. U. 2004. Rozporządzenie Ministra Środowiska z dn. 28 września 2004 r. w sprawie gatunków dziko występujących zwierząt objętych ochrona, nr 220, poz. 2237.

EPLER P \& BIENIARZ K. 1974. Influence of heated discharge waters from the Skawina Electric Power Station on the ichthyofauna of the rivers Skawinka and Vistula. Acta Hydobiologica 15: 331-339.

Galicka W., Grabowska J., Kruk A., Penczak T., Marszal L., Tszyndel M., TybulczUk S. \& Pietraszewski D. 2011. Fish fauna of the Ner River in the City of Lódź - present state and changes over the last decade. Acta Universitatis Lodziensis, Folia Biologica et Oecologica: Suppl., p. 55-67. [In Polish with English abstract]

GlowActŃski Z. (ed.) 2001. Polish Red Data Book of Animals - Vertebrates. Panstwowe Wydawnictwo Rolnicze i Leśne, Warszawa, 449 pp. 
GRABOWSKA J., WITKOWSKI A., KOTUSZ J. 2008. Inwazyjne gatunki ryb w polskich wodach -zagrożenia dla rodzimej ichtiofauny. In: MIZIELIŃSKI M. (ed.), Użytkownik rybacki - nowa rzeczywistość, pp. 90-95. Wydawnictwo Polskiego Związku Wędkarskiego, Warszawa.

GRABOWsKa J., KotUsz J., WitKoWski A. 2010. Alien invasive fish species in Polish waters: an overview. Folia Zoologica 59: 73-85.

GUZIUR J. \& WOŹNIAK M. 2006. Produkeja ryb w malych zbiornikach. Oficyna Wydawnicza „HOŻA”, Warszawa, 323 $\mathrm{pp}$.

HOLC̆IK J. 1972. Abundance, ichthyomass and production of fish populations in three types of water-bodies in Czechoslovakia. In: KAJAK Z. \& HILBRICHT-ILKOWSKA A. (eds), Productiviy problems of freshwaters. Polish Scientific Publishers, pp. 834-855. Warsaw.

HOLČIK J. \& BASTL I. 1976. Ecological effects of water level fluctuations upon the fish populations of the Danube River floodplain in Czechoslovakia. Acta Scientiarum Naturalium Academiae Scientiarium Bohemoslovace, Brno, 9: 1-46.

JARZYNOWA B., RADWAN S. \& GIRSZTOWTT Z. 1990. Age and growth of more abundant fish species compared with fisheries and fish stocking in the Zemborzye reservoir. Roczniki Naukowe Polskiego Związu Wędkarskiego 3: 33 46. [In Polish with English abstract]

KALINOWSKI L. 1991. Troé w Odrze pod Wrocławiem. Wędkarz Polski 2: 25

KAPUSTA A., MORZUCH J., PARTYKA K. \& BOGACKA- KAPUSTA E. 2010. First record of brown bullhead, Ameiurus nebulosus (Lesueur), in the Lyna River drainage basin (northeast Poland). Archive Polish Fisheries $18: 261-265$.

KLESZCZ M., MATURA M. \& WITKOWSKI A. 2001. Certa - Vimba vimba (L.): Udana próba produkcji materiału zarybieniowego i restytucji środkowym dorzeczu Odry. Komunikaty Rybackie 1: 15-17.

KLESZCZ M., WITKOWSKI A. \& WOLNICKI J. 2002. Miętus Lota lota (L.) w Ośrodku Zarybieniowym PZW Szezodre. II. Produkcja materiału zarybieniowego w stawach i efektywność zarybień rzek. Komunikaty Rybackie 1:27-29.

KostRzEwA J. 2000. Wplyw degradacji rzeki na ichtiofaunę w jej doplywach. Lodz University, PhD dissertation, (msc).

KoTUSZ J. 2008. Morphological relationships between polyploid hybrid spined loaches of the genus Cobitis (Teleostei: Cobitidae) and their parental species. Annales Zoologici 58 (4): 891-905.

Kotusz J., KuszNIERZ J. \& WitKowski A. 1996. The ichthyofauna of the Bystrzyca River drainage basin (mid-Odra basin). Roczniki Naukowe Polskiego Związku Wędkarskiego 9: 63-90. [In Polish with English abstract]

Kotusz J., WitKowski A., Blachuta J. \& Kuszinierz J. 2001. Present fish fauna of the upper and middle Odra catchment. Roczniki Naukowe Polskiego Związku Wędkarskiego 14 (sup1.): 297-310. [In Polish with English abstract]

Kotusz J., WitKowski A., BEACHUTA J. \& BARAN M. 2006. Fish migrations in a large lowland river (Odra R., Poland) - based on fish pass observations. Folia Zoologica 55: 386-398.

KOZIKOWSKA Z. 1974. Les poissons dans la nourriture des habitants medievaux de L'ile-du-dome a Wroclaw, come indice des especes peches dans les eaux des regions donnees ou des especes qui y parvenaient par commerce. Prace Zoologiczne Acta Univ. Wratisl. 6: 3-14. [In Polish with Franch abstract]

Kruk A., Penczak T., Galicka W., Koszaliński H., TeoczeK K., Kostrzewa J., \& Marszaz L. 2000. Ichthyofauna of the Warta River. Roczniki Naukowe Polskiego Związk Wędkarskiego 13: 35-67. [In Polish with English abstract]

KRUK A., PENCZAK T. \& PRZYBYLSKI M. 2001. Long term changes in the fish fauna of the upper Warta River. Roczniki Naukowe Polskiego Związku Wędkarskiego 14 (Supp1.): 189-211. [In Polish with English abstract]

KRUK A. \& PRZYBYLSKI M. 2005. Occurrence of fish in the Warta River sections of different degradation level. Roczniki Naukowe Polskiego Związku Wędkarskiego 18: 47-57. [In Polish with English abstract]

KRUK A., SZYMCZAK M. \& SPYCHALSKI P. 2003. Ichthyofauna of the City of Lódź. Part I. Systems of the Jasień and Lódka streams. Roczniki Naukowe Polskiego Związu Wędkarskiego 16: 79-96. [In Polish with English abstract]

KRUK A., SPYCHALSKT P. \& GALICKA W. 2005. Ichthyofauna of the City of Lódź. Part II. System of the Sokotow stream. Roczniki Naukowe Polskiego Związku Wędkarskiego 18: 29-46. [In Polish with English abstract]

KUSZNIERZ J. 1998. Biology of the swamp minnow Moroco (=Phoxinus) percmurus (Pallas, 1811) (Pisces , Cyprinidae). Wrocław University, Ph.D dissertation (msc).

KUSZNIERZ J., WOLNICKI J., KAMINSKI R. \& MYSZKOWSKI L. 2002. Strzebla błotna Eupallasella percnurus (Pallas, 1811) - historia, zagrożenia i pespektywy ochrony. Komunikaty Rybackie 2: 11-13.

MALACHOWICZ E. 2000. Najnowszy zarys dziejów najstarszego Wroclawia. PWN Wrocław, 48 pp.

Marsza L., ZięBa G., KruK A., Tybulczuk S., Pietraszewski D., Tszyndel M., Kapusta L., Galicka W. \& PENCZAK T. 2009. Fish fauna of the left side tributaries of the Polish-Ukrainian section of the Bug River. Roczniki Naukowe Polskiego Związku Wędkarskiego 22: 87-117. [In Polish with English abstract]

Marsza L., ZięBa G., KruK A., Tszyndel M., TybulczuK S., Pietraszewski D., Galicka W. \& JantC B. 2011. Ichthyofauna of streams in the Vistula system in the City of Lodź. Acta Universitatis Lodziensis, Folia Biologica et Oecologica: Supplementum, 89-111. [In Polish with English abstract]

NELSON J. S. 2006. Fishes of the Word. $4^{\text {th }}$ edition Publisher. J. Wiley \& Sons, Inc. Hoboken, New Jersey. 
OBERDORFF T. \& HUGHES R. 1992. Modification of an index of biotic integrity based on fish assemblages to characterize rivers of the Seine basin, France. Hydrobiologia 228; 117-130.

PADUSZEK D. 2000. Biometria sumika karłowatego Ictalurus nebulosus (Le Sueur, 1819) ze stawów terenów Wodonośnych Wrocławia (zlewnia Oławy). Wroclaw University, Museum of Natural History (msc).

PAX F. 1925. Wirbeltierfauna von Schlesien. Faunistische und tiergeographische Unteresuchungen im Odergebiet. 5. Pisces, 516-537 pp. Verlag von Gebrüder Borntraeger, Berlin.

PENCZAK T. 1967. The biological and technical principles of the fishing by use of direct-current field. Przegląd Zoologiczny 11: 114-131.

PENCZaK T., Kostrzewa J., Marszat L., Koszalniski H. \& KRUK A. 1999. Fish fauna of the Noteć River. Roczniki Naukowe Polskiego Związku Wędkarskiego 12: 81-94. [In Polish with English abstract]

PENCZAK T. \& KRUK A. 2004. Threatend obligatory riverine fishes in human-modified Polish rivers. Ecology of Freshwater Fish 9: 109-117.

Penczak T., KruK A., Kostrzewa J., Marsza L., Galicka W. \& Głowacki L. 2000. Fishes of three oxbow lakes and their parent Pilica River: 25 years later. Polskie Archiwum Hydrobiologii 1: 115-130.

Penczak T., Kruk A., Koszaliński H. Marszal L., ZięBa G., Kostrzewa J., \& Tybulczuk S. 2004. Fish fauna of the Prosna River system. Part II. Tributaries. Roczniki Naukowe Polskiego Związku Wędkarskiego 17: 55-76. [In Polish with English abstract]

PENCZAK T., ZIĘBA G., KOSZALIŃSKI H. \& KRUK A. 2003. The importance of oxbow lakes for fish recruitment in a river system. Archiv für Hydrobiologie 158: 267-281.

Pietraszewski D., Marsza£ L., Kruk A., Penczak T., Zięba G., Grabowska J., Koszaliniski H. \& Tybulczuk S. 2008. Preliminary study of fish and lamprey distribution in the Radomka River and its main tributaries. Roczniki Naukowe Polskiego Związu Wędkarskiego 21: 91-104. [In Polish with English abstract]

Radwan S., Jarzynowa B., Zwolski W., Girsztowtt Z., Kowalczyk C. \& Paleolog A. 1988. Ecological characterization of the waters of the upper and midde courses of the Bystrzyca River, its tributaries and the Zemborzyce lake. Roczniki Naukowe Polskiego Związku Wędkarskiego 1: 123-156. [In Polish with English abstract]

RAPORT 2010. Raport o stanie środowiska w województwie Dolnośląskim w roku 2009. Biblioteka Monitoringu Środowiska, Wroclaw $2009,99 \mathrm{pp}$.

RECHLLICZ J. 2008. Wpływ regulacji koryta rzeki miejskiej na skład gatunkowy ryb na przykładzie wybranego fragmentu rzeki Czerniejowki. In: MOKWA M. \& WIŚNIEWOLSKI W. (ed.), Ochrona ichtiofauny w rzekach z zabudową hydrotechniczna, pp. 74-80. Dolnośląskie Wydawnictwo Edukacyjne, Wrocław.

REMBISZEWSKI J.M. \& ROLIK H. 1975. Kragłoste i ryby - Cyclostomata et Pisces. 38. Katalog fauny Polski. Państwowe Wydawnictwo Naukowe, $251 \mathrm{pp}$.

SCHIEMER F. \& WAIDBACHER H. 1991. Strategies of conservation of a Danubian fish fauna. - River Conservation and Management. Wiley and Sons Ltd.

SCHEMER F. \& WIESER W. 1992. Epilogue: food and feeding ecomorphology, energy assimilation and conversion in cyprinids. Environmental Biology of Fishes 33: 223-227.

SŁowO POLSKIE 2002. Zabłąkany losoś w Odrze. Niecodzienne trofeum. Slowo Polskie On-Line, Wrocław, 02.04 .2002 .

STANI M. 2005. Revitalization of the Zemborzyce Reservoir in Lublin. Teka Komisji Architektury, Urbanistyki i Studiów Krajobrazowych, Oddział Lubelski PAN, 2005: 177-182. [In Polish with English abstract]

SZCZEPAŃSKI W. (ed.) 1996. Atlas posterunków wodowskazowych dla potrzeb państwowego monitoringu środowiska. Biblioteka Monitoringu Środowiska, Warszawa 1995-1996.

WELCOMME R.L. 1985. River fisheries. FAO Fisheries Technical Paper (262): 330 pp.

WIŚNIEWOLSKI W., BORZECKA I., BURAS P., SZLAKOWSKI J. \& WOŹNIEWSKI M. 2001. Fish fauna of the lower and middle Vistula River - present state and threats. Roczniki Naukowe Polskiego Związku Wędkarskiego 14 (Suppl.): 137-155. [In Polish with English abstract]

WIŚNIEWOLSKI W. \& ENGEL J. (eds). 2006. Restoring migratory fish and connectivity of rivers in Poland. Publisher IRS \& WWF Polska, Olsztyn, 82 pp.

WIŚNIEWOLSKI W. \& LIGIĘZA J. 2011. Ichtiofauna wybranych zbiorników wodnych oraz Wisły w Warszawie. Fragmenta Funistica 54 (1): 59-76.

WITKOWSKI A. 1973. Barbus petenyi Heckel, 1847, in the river Bystrzyca near Lublin. Przegladd Zoologiczny 17: 375 376. [In Polish with English abstract]

WiTKOWsKI A. 1984a. The analysis of the Biebrza River system. Part II. Materials to the knowledge of ichthyofauna and review of species. Fragmenta Funistica 28:137-184.

WITKOWSKI A. 1984b. Structure of fish community and biomass of the ichthyofauna in the Biebrza river, its old river beds and affluents. Polish Ecological Studies 10: 215-242.

WITKOWSKI A. 1994a. Morhological variability of Sabanejewia aurata (De Filippi, 1865) from the Odra River basin, with description of a new subspecies (Teleostei: Cypriniformes: Cobitidae). Zoologische Abhandlungen aus dem Staatlichen Museum für Tierkunde in Dresden 48: 23-51. 
WITKOWSKI A. 1994b. Ichthyofauna of the Biebrza River basin. In: OKRUSZKo H. \& WASSSEN M. J. (eds), Towards protection and sustainable use of the Biebrza Wetlands, pp. 459-480. Utrecht, The Netherlands.

WiTKowski A. 2003. The huchen Hucho hucho (L.) (Salmonidae) - a species saved for the Polish ichthyofauna. Supplementa at Acta Hydrobiologica 6: 109-213.

WITKOWSKI A. 2009. On the expansion and occurrence of an invasive species - Pseudorasbora parva (Temminck et Schlegel, 1846) (Teleostei: Cyprinidae: Gobioninae) in Poland. Fragmenta Funistica 52: 25-32.

Witkowski A., BARTEL R. \& KLESzCZ M. 2001. Successful fish restitutions in Poland. Roczniki Naukowe Polskiego Związu Wędkarskiego 14 (Suppl.): 83-90. [In Polish with English abstract]

WITKOWSKI A., BARTEL R., KOLMAN R. \& WIŚNIEWOLSKI W. 2004a. The realization of a program for restituting migratory fishes in the Vistula and Oder River systems. Archives of Polish Fisheries 12 (supl. 2): 309-325. [In Polish with English abstract]

WiTKOWSKI A. \& BeACHUTA J. 1989. A natural hybryd Lenciscus idus (L.) x Leuciscus cephalus (L.) from the Odra River (Osteichthyes, Cypriniformes, Cyprinidae). Zoologische Abhandlungen aus dem Staatlichen Museum für Tierkunde in Dresden 45: 1-10.

WiTKOWSKI A. \& BŁACHUTA J. 1991a. Ichthyofauna of streams of the Ślęża Massif. Acta Universitatis Wratislaviensis - Prace Zoologiczne 13: 105-122. [In Polish with English abstract]

WITKOWski A., BŁACHUTA J. \& DOBICKI W. 1992a. Ichtiofauna rzeki Olawy na tle warunków środowiskowych. In: Kamapnia na rzecz odnowy biologicznej rzeki Oławy, pp. 45-53. Polskie Towarzystwo Hydrobiologiczne \& G. Marshall Fundation, Wroclaw.

WitKowski A., BLACHUTA J., KLESZCZ M. \& NAPORA K. 2002. Realizacja projektu restytucji ryb dwuśrodowiskowych w gómym i środkowym dorzeczu Odry. Komunikaty Rybackie 3: 13-16.

WitKowski A., BŁachutA J., KotUsz J.\& KuszNIERZ J. 2000. The lampreys and fishes of the rivers upper and middle Odra basin (Silesia, SW Poland) - The present situation. Acta Hydrobiologica 43: 283-303.

Witkowski A., BeAChUTA J. \& KUSZnERZ J. 1990. Golden loach, Sabanejewia aurata (de Filippi, 1856) in the Widawa - second locality in the Odra basin. Przegląd Zoologiczny 34: 309-313. [In Polish with English abstract]

WITKOWSKI A., BŁACHUTA J. \& KUSZNIERZ J. 1991b. Ichthyofauna of theWidawa River drainage basin after regulation. Roczniki Naukowe Polskiego Związku Wędkarskiego 4: 45-46. [In Polish with English abstract]

WitKowski A., Blachuta J., KusznieRz J. \& KOlACZ M. 1992b. Ichthyofauna of the Ślęża and Oława Rivers and their tributaries. Roczniki Naukowe Polskiego Związku Wędkarskiego 5: 137-154. [In Polish with English abstract]

WitKowski A., KLESzCZ M., HeEse T. \& MARTYNIAK A. 2004. Vimba Vimba vimba (L.) of the Oder River system: history, current status and perspectives. Archives of Polish Fisheries 12 (supl. 2): 103-157. [In Polish with English abstract]

WiTKowski A. \& KoTUSz J. 2003. Pirapitynga, Piaractus brachypomus (Cuvier, 1818) (Serrasalmidae: Osteichthyes) in Poland - another introduced species. Przegląd Zoologiczny 47: 221-224. [In Polish with English abstract]

Witkowski A., KotUsz J., Baran M., BıAchuta J. \& NaPora K. 2004c. Przechodzenie ryb przez przepławkę "Wały Ślaskie" na Odrze. Komunikaty Rybackie 3:1-4

WitKowski A., KotUsz J. \& PRZYBYLSKI M. 2009. The degree of threat of the freshwater ichthyofauna of Poland: Red list of fishes and lampreys - situation in 2009. Chrońmy Przyrodę Ojczystą 65: 33-52. [In Polish with English abstract]

WITKOWSKI A. \& PASZKOWSKI P. 2002. The impact of ponds and hatcheries on the ichthyofauna of the Dobra river (a Central Oder River tributary). Archives of Polish Fisheries 10: 207-219.

WitKowski A., PAszkowski P. \& KotUsz J. 2007a. Impact of fish ponds on the ichthyofauna of a small lowland river. Inżynieria Ekologiczna 1: 301-303. [In Polish with English abstract]

Witkowski A., PENCZAK T., KotUsz J., PRZYByLski M., KRUK A.\& BEACHUTA J. 2007b. Reophilous cyprinid fishes of the Odra River basin. Roczniki Naukowe Polskiego Związku Wędkarskiego 20: 5 -33. [In Polish with English abstract]

WITKOWSKI A. \& WIŚNIEWOLSKI W. 2005. Fishes and lampreys of the Biebrza River, its tributaries and oxbows. In: DYRCZ A. \& WERPACHOWSKi C. (eds), Przyroda Biebrzańskiego Parku Narodowego, pp. 247-255. Wydawnictwo Biebrzańskiego Parku Narodowego, Osowiec-Twierdza.

WiTKOWski A. \& ŻERELIK R. 2001. Wykaz ryb Śląska z połowy XIV wieku. In: ŻERELIK R. (ed.), Studia z Dziejów Śląska i Wielkopolski, pp. 167-178. Instytut Historii, Uniwersytet Wrocłąwski, Wrocław.

WLODEK J. M. \& SKÓRA S. 1993. Ichthyofauna of the river Vistula in the area of Great Cracow during last 100 years. Studia Ośrodka Dokumentacji Fizjograficznej PAN 21:245-263. [In Polish with English abstract]

WOLTER C. 2001. Rapid changes of fish assemblages in artificial lowland waterways. Limnologica 31: 27-35.

Wolter C., Bischoff A., TAUTENHAHN M. \&VILCINSKAS A. 1999. Die Fischfauna Unteren Odertals: Arteninventar, Abundanzen, Bestandsentwicklung und Fischökologie Bedeutung der Polderflächen. Limnologie Aktuell 9: 369 386.

WOLTER C., MINOW J., VILCINSKAS A. \& GROSCH U. A. 2000. Long-term effects of human influence on fish community structure and fisheries in Berlin waters: an urban water system. Fisheries Management and Ecology 7 : 97-104. 
WOLTER C. \& VIlCINSKAS A. 1997. Perch (Perca fluviatilis) as an indicator species for structural degradation in regulated rivers and canals in the lowlands of Germany. Ecology of Freshwater Fish 6: 174-181.

WOEOS A. 1999. Wielkość i struktura odłowów wędkarskich. In: WOEOS A. (ed.), Stan rybactwa jeziorowego w 1998 roku, pp. 13-20. Wydawnictwo IRS, Olsztyn.

WOEOS A. \& MICKIEWICZ M. 2001. Characteristics of angling presssure, anglers and commercial catches in the Vistula River between Smoszewo and Wyszogród. Roczniki Naukowe Polskiego Związku Wędkarskiego 14: 39-53. [In Polish with English abstract]

ŻERELIK R. 2002. Dzieje Śląska do 1526 roku. In: CZAPLn'́SKI M. (ed.), Historia Śląska. Wydawnictwo Uniwersytetu Wrocławskiego, pp. 11-114. Wrocław.

\section{STRESZCZENIE}

\section{[Ichtiofauna Wroclawia - Odry, jej doplywów i wybranych akwenów śródmiejskich]}

Scharakteryzowano aktualna ichtiofaune Odry ujściowych partii jej największych doplywów (Olawa, Widawa, Bystrzyca, Ślęża) oraz wybranych zbiorników (glinianki, sadzawki i stawy parkowe, kapieliska miejskie, fosa miejska) obszaru miejskiego Wroclawia. Dane dotyczace stanu ichtiofauny uzyskano w wyniku wlasnych badań (elektropolowy i polowy sieciowe), odlowów bonitacyjnych PZW, analizy protokolów zarybieniowych, kontroli i analizy rejestrów polowów wędkarskich oraz wywiadów z wędkarzami, prowadzonych od 1980 do 2010 roku. Łacznie stwierdzono na obszarze aglomeracji wroclawskiej obecność 46, z czego w Odrze 42 (11-39), jej doplywach 41 (9-34) gatunków ryb i minogów. W zbiornikach śródmiejskich, których ichtiofauna jest formowana glównie poprzez zarybienia odnotowano łacznie 28 (1-13) gatunków, należących do eurytopowej i stagnofilnej grupy ekologicznej. W akwenach Wroclawia występuje 9 gatunków chronionych (Lampetra planeri, Acipenser oxirynchus, Gobio albipinnatus, Rhodeus sericeus, Eupallasella percnurus, Cobitis taenia, Sabanejewia baltica (=aurata), Misgurnus fossilis, Barbatula barbatula) i 5 (Vimba vimba, Barbus barbus, Chondrostoma nasus, Hucho hucho, Salmo salar) zagrożonych w Polsce. Ponadto stwierdzono w ciekach i akwenach Wrocławia stale lub sporadyczne występowanie 11 gatunków ryb i minogów (Lampetra planeri, Acipenser oxirynchus, Gobio albipinnatus, Rhodeus sericeus, Aspius aspius, Eupallasella percnurus, Cobitis taenia, Sabanejewia baltica (=aurata), Misgurnus fossilis, Hucho hucho, Salmo salar) objętych europejską ochroną sieci Natura 2000. Występuje tu również 10 celowo lub przypadkowo introdukowanych gatunków (Cyprinus carpio, Carassius gibelio, Ctenopharyngodon idella, Hypophthalmichthys molitrix, Aristichthys nobilis, Pseudorasbora parva, Piaractus brachypomus, Ameiurus nebulosus, Oncorhynchus mykiss, Hucho hucho). Na wroclawskim odcinku Odry zanikło na początku XX w., lub przestało tu docierać 8 gatunków ryb i minogów: Petromyzon marinus, Lampetra fluviatilis, Alosa alosa, Osmerus eperlanus, Pelecus cultratus, Acipenser oxirynchus, Salmo salar, S. trutta $\mathrm{m}$. trutta $-\mathrm{z}$ których trzy ostatnie przywraca się temu obszarowi. Mimo dhugoletniego wplywu skanalizowania i przegrodzenia biegu Odry licznymi tamami, jazami i śluzami oraz wysokiej antropogenicznej presji (w tym natężonych polowów wędkarskich), we wroclawskich wodach występują zróżnicowane gatunkowo, a w Odrze bogate liczebnie zespoly ryb. 